\title{
La planificación territorial de las actividades extractivas: Comentario crítico al Plan Sectorial de Canteras de Illes Balears
}

\author{
Jaume Munar Fullana \\ Profesor Asociado de Derecho Administrativo \\ de la Universitat de les Illes Balears
}

\begin{abstract}
Sumario: I. INTRODUCCIÓN. II. EL MARCO NORMATIVO. III. LA REGULACIÓN DE LA ACTIVIDAD EXTRACTIVA SOBRE EL TERRITORIO EN EL PDS. 1. Catalogación de las actividades existentes. 2. Ubicación de nuevas canteras. 3. Cobertura legal de las determinaciones territoriales del PDS. IV. LOS PLANES DE RESTAURACIÓN. SU PROBLEMÁTICA INCARDINACIÓN EN EL PDS. V. COMPETENCIAS DEL MUNICIPIO E INCIDENCIA DE LAS DETERMINACIONES DEL PDS. VI. INSPECCIÓN Y CONTROL DE LOS PLANES DE RESTAURACIÓN Y FIANZAS DE RESTAURACIÓN. VII. LA POSIBLE REUTILIZACIÓN DE LAS CANTERAS PARA USOS NO EXTRACTIVOS. VIII. LA REVISIÓN DEL PDS DE CANTERAS Y LA LEY DE DIRECTRICES DE ORDENACIÓN TERRITORIAL. IX. LAS PREVISIONES DEL PDS CON CONEXIÓN A OTROS TÍTULOS DE HABILITACIÓN. 1. Naturaleza jurídica de las previsiones del Plan en materia minera y medioambiental. 2. Iters procedimentales y posibilidades de convalidación. 3. El posible desarrollo de las determinaciones del PDS. X. CONCLUSIONES.
\end{abstract}

\section{INTRODUCCIÓN}

Con la Ley 8/1987, de 1 de abril, de Ordenación Territorial de Baleares (LOT/87), aparece en nuestra comunidad autónoma la norma de referencia que crea los instrumentos de planificación necesarios para la consecución de los objetivos que se fijan para ese sector del ordenamiento jurídico. Se parte para ello de la creación de una figura central, las Directrices de Ordenación Territorial, norma con rango legal cuyas determinaciones vincularán al resto de instrumentos de naturaleza administrativa: planes territoriales insulares, planes directores sectoriales y planes de ordenación del medio natural.

En este sentido, su artículo 6 disponía que los Planes Directores Sectoriales (PDS) debían regular el planeamiento, proyección, ejecución y gestión de los sistemas generales de infraestructuras, equipamientos, servicios y actividades de explotación de recursos, de forma que la actuación de las distintas administraciones respondiese a los criterios de las Directrices de Ordenación Territorial y a programas establecidos previamente.

Avanzamos ya en este momento que dicha norma legal ha sido derogada y sustituida por la Ley 14/2000, de 21 de diciembre (LOT/2000), de 
idéntica denominación que la anterior y que ha comportado, entre otras cosas, la reconfiguración del papel de los distintos instrumentos de ordenación previstos a la vez que una reasignación competencial orgánica para adecuarla a la también más reciente nueva Ley 8/2000, de 27 de octubre, de Consells Insulares (LCI). La nueva Ley de Ordenación Territorial ha comportado igualmente la supresión de la figura de los Planes de Ordenación del Medio Natural y el cambio de denominación de Planes Territoriales Parciales a Planes Territoriales Insulares (PTI), en armonía con la asignación al correspondiente consell de la competencia para su elaboración y aprobación, pero manteniéndose esencialmente el régimen de regulación sustantiva de los PDS, aunque ahora asignándose facultades para su redacción y aprobación tanto al Govern como a los consells insulares.

Ya disponía la LOT/87 que los PDS podrían ser elaborados por el Govern Balear o por el Consell Insular respectivo según especificaciones de las Directrices de Ordenación Territorial, aunque en ausencia de ellas, su disposición transitoria única disponía que si razones de urgencia aconsejaren la redacción de un Plan Territorial Parcial, un Plan Director Sectorial o un Plan de Ordenación del Medio Natural, con anterioridad a la aprobación de las Directrices de Ordenación Territorial, el Consell de Govern podría autorizar su elaboración, «previa aprobación por el Parlamento de las Islas Baleares de los criterios generales a que dicho Plan deba acomodarse, así como que Institución elaborará dicho Plan». Las Directrices de Ordenación Territorial no resultan aprobadas hasta la Ley 6/1999, de 3 de abril (LDOT), que entra en vigor el 18 siguiente.

En ese contexto, y en uso de la disposición transitoria de la LOT/87 antes citada, mediante el Decreto 77/1997, de 11 de junio, se aprueba definitivamente el PDS de Canteras de las Illes Balears, siendo objeto de revisión mediante el Decreto 61/1999, de 28 de mayo, que aprueba definitivamente dicha revisión del citado instrumento, y que constituirá el objeto básico de nuestro estudio. Análisis que realizaremos desde una doble vertiente: del contenido estricto de las determinaciones del plan y en concreto del posible exceso del planificador territorial en uso de su título habilitante, así como de la problemática actual que el régimen de distribución competencial institucional intracomunitaria puede generar en la aplicación o modificación de las referidas determinaciones. Para ello se hace del todo necesario, aunque sea resumidamente, efectuar algunas precisiones iniciales.

El artículo 10.3 del Estatuto de Autonomía de las Illes Balears otorga a nuestra comunidad autónoma, con carácter exclusivo, la potestad legislativa, reglamentaria y ejecutiva en materia de ordenación del territorio, 
incluido el litoral, urbanismo y vivienda, título que lleva aparejado la posibilidad de aprobación de las leyes referenciadas más arriba y, derivadamente, la de los planes de ordenación territorial. El artículo 11 de la norma estatutaria posibilita a la vez que, en el marco de la legislación básica del Estado y, si procede, en los términos que ésta establezca, la CAIB podrá asumir el desarrollo legislativo y ejecución en materia de «protección del medio ambiente y normas adicionales de protección»y de «régimen minero y energético».

A ello se añade que nuestra norma estatutaria configura a los consells insulares como entes de gobierno, administración y representación de las islas de Mallorca, Menorca e Ibiza y Formentera, habilitándoles para asumir en su ámbito territorial las funciones ejecutiva y de gestión de una larga lista de materias. Así, el artículo 39 del Estatuto establece para los consells insulares la facultad de asumir dentro de su ámbito territorial, además de las competencias que les correspondan como corporaciones locales, la función ejecutiva y la gestión, en la medida en que la comunidad autónoma asuma competencias, entre otras en las de «ordenación del territorio, urbanismo y vivienda, medio ambiente y ecología», según dispone el número 8 del citado precepto. Este aspecto deberá tenerse siempre en cuenta a la hora de la aplicación práctica de la norma estudiada, en lo referente a los ámbitos de intervención de la Administración autonómica.

En esta línea, la Ley 9/1990, de 27 de junio, dio comienzo al proceso de transferencias de competencias a dichos entes mediante la atribución de las relativas a urbanismo y habitabilidad, y cuyo último exponente ha sido por el momento la reciente Ley $2 / 2001$, de 7 de marzo, de atribución de determinadas competencias en materia de ordenación del territorio, norma legal esta última dictada ya en el contexto de la vigencia de la nueva LCI que perfila de forma más precisa el escenario para la formulación de políticas territoriales y urbanísticas en nuestra comunidad autónoma ${ }^{1}$.

Respecto a otros títulos competenciales que veremos resultan invocados en el vigente Decreto de aprobación definitiva del PDS -medio ambiente y régimen minero-, el citado artículo 39 del EA únicamente alude al primero como susceptible de asunción por parte de los consejos insulares a través de facultades ejecutivas y de gestión, aunque se debe tener en cuenta que la relación del citado precepto no es exhaustiva desde

\footnotetext{
${ }^{1}$ La ley de transferencia en materia de ordenación del territorio atribuye competencia a los consells insulares, en lo que ahora interesa, para la elaboración y aprobación del PDS de Canteras -art. 1.2.a)-.
} 
el momento en que contempla una cláusula de atribución de cualquiera otras materias que dentro del ámbito territorial propio correspondan a los intereses respectivos, de acuerdo con las transferencias o delegaciones que a tal fin se establezcan. Pero hasta la fecha, ninguna de estas dos materias ha resultado atribuida a los consells insulares.

En resumen, analizaremos un PDS regulador de una actividad de explotación de recursos aprobado bajo el amparo de la LOT/87 y mediante un procedimiento excepcional en ausencia de Directrices de Ordenación en el momento de su aprobación inicial, pero ya con la vigencia del instrumento legal de referencia en el trámite de su aprobación definitiva, aspecto que debería haber incidido especialmente en su contenido. Se añadirá a ello posteriormente un factor igualmente importante al que ya se ha hecho mención, como es el haberse realizado una atribución competencial para la elaboración y aprobación de dicho instrumento en favor de los consells insulares en el año 2001, que condicionará, como veremos, el alcance que pueda ahora tener la modificación o nueva revisión del plan.

Comenzaremos en cualquier caso, realizando una breve aproximación a uno de los aspectos centrales del plan, como es el objeto y alcance de su regulación material y en que medida se pueden considerar sus determinaciones como propias de un instrumento de ordenación territorial.

\section{EL MARCO NORMATIVO}

Para valorar el alcance de la habilitación que el marco legal confiere al planificador de ordenación territorial en la materia que nos ocupa, resulta obligado acudir a las determinaciones que para la figura de los PDS se establecían en la LOT/87, vigente en el momento de dictarse el que se constituirá en objeto de nuestro estudio. Se conceptúa a dicha figura como instrumento regulador del planeamiento, proyección, ejecución y gestión de los sistemas generales de infraestructuras, equipamientos, servicios y actividades de explotación de recursos, de forma que la actuación de las distintas administraciones responda a los criterios de las Directrices de Ordenación Territorial y a programas establecidos previamente; dicha definición se recogerá prácticamente en los mismos términos en el actual artículo 11 de la vigente LOT/2000².

\footnotetext{
2 «Los planes directores sectoriales son los instrumentos de ordenación específica que tienen por objeto regular, en ámbitos materiales determinados, el planeamiento, la proyección, la ejecución y la gestión de los sistemas generales de infraestructuras, equipamientos, servicios y actividades de explotación de recursos».
} 
En consecuencia, la habilitación al planificador deriva de las previsiones de una Ley autonómica dictada en el ejercicio de la competencia exclusiva en materia de ordenación del territorio, ex artículo 10.3 del EA. En cualquier caso, el propio planificador reconocerá expresamente que convergen a la hora de la elaboración y aprobación del PDS tres títulos competenciales habilitantes. En este orden de cosas, la parte expositiva del Decreto de aprobación definitiva del plan aludirá a dos preceptos diferentes de la norma estatutaria:

- El artículo 10.3, que dispone la competencia exclusiva de la Comunidad Autónoma en «ordenación del territorio, incluido el litoral, urbanismo y vivienda».

- El artículo 11, en sus puntos 13 y 14, que asigna igualmente competencia en el marco de la legislación básica del estado y, si procede, en los términos que esta legislación establezca, para el desarrollo legislativo y ejecución de «normas adicionales de protección del medio ambiente» $\mathrm{y}$ 《régimen minero y energético» ${ }^{3}$.

La invocación de diversos títulos habilitantes desembocará hacia una problemática que constituye en gran parte el objeto del presente estudio, que no será otra que la relativa al alcance posible del contenido material del PDS en su conexión con el segundo título de habilitación. Más concretamente, la posibilidad de que un instrumento de ordenación territorial, con un procedimiento de elaboración específicamente contemplado en la LOT/87, y por tanto diferente del procedimiento exigido para llevar a cabo el desarrollo legislativo -normativo en sentido amplio- de la legislación básica del estado en materia ambiental y minera, pueda contener determinaciones relacionadas con estos sectores comportará, como decimos, la necesidad de clarificar su alcance y efectividad real.

Apuntado este primer aspecto en referencia a las específicas fuentes de habilitación, se debe complementar con la constatación del hecho que, en su ánimo de exhaustividad, olvida el planificador hacer mención a un cuarto sector del ordenamiento jurídico implicado, como será el relativo al patrimonio histórico y cultural de interés para la Comunidad Autónoma, materia sobre la que se ostenta por parte de la CAIB competencia exclusiva y que igualmente dará cobertura a algunas de las determinaciones del PDS, como tendremos ocasión de apuntar.

\footnotetext{
3 Actualmente, la referencia debe entenderse a los puntos 7 y 10 del expresado artículo 11, de acuerdo con la redacción conferida por la Ley Orgánica 3/1999, de 8 de enero, de reforma del Estatuto de Autonomía.
} 


\section{LA REGULACIÓN DE LA ACTIVIDAD EXTRACTIVA SOBRE EL TERRITORIO EN EL PDS}

El objeto del PDS se concreta en el artículo 1 del anexo normativo del Decreto que lo aprueba definitivamente señalándose en este sentido que «este Plan tiene por objeto regular el planeamiento, la gestión y la restauración de las canteras en el ámbito territorial de la Comunidad Autónoma de las Illes Balears, de manera que ocasionen el menor impacto medioambiental posible», apuntándose igualmente en el artículo 2 que, en desarrollo de lo dispuesto en el anterior, su finalidad se concreta en los siguientes puntos:

1. Definir y regular las áreas de ubicación de las canteras, de acuerdo con el principio de autoaprovechamiento prioritario de cada una de las islas y, en la medida que sea posible en Mallorca, de las distintas zonas, partiendo de unos criterios de protección del medio ambiente.

2. Establecer el control medioambiental de los planes de restauración de las canteras, de su reexplotación, o de los proyectos de reutilización de estas.

No sorprenderá entonces que la definición de cantera establecida en el PDS vaya ligada al factor de su entorno físico, puesto que se entiende como tal a «todo espacio objeto de actividad minera a cielo abierto destinado al aprovechamiento de rocas o recursos minerales, así como las actividades extractivas subterráneas cuya ejecución pueda deteriorar el entorno medioambiental circundante» aclarando el redactor del plan que «ambos casos se referirán tanto a las actividades sujetas a autorización de aprovechamiento como a las que formen parte de una concesión de explotación».

Con relación a los objetivos señalados, el Tribunal Superior de Justicia de las Islas Baleares (TSJIB) perfila la suficiencia e idoneidad de un plan director sectorial, que en definitiva llevará a cabo una mera función delimitadora del derecho de propiedad que tiene encaje en la planificación, no siendo necesaria reserva legal para dicha medida. Señalará así, en su sentencia . $^{\circ}$ 963/2002, de 22 de noviembre de 2002, que «la planificación, gestión y restauración de las canteras no tiene porqué suponer una restricción al derecho de la propiedad, porque no existe un derecho absoluto e ilimitado a la explotación de los recursos mineros, máxime cuando los yacimientos de origen natural y demás recursos geológicos son de dominio público (art. $2^{\circ}$ Ley de Minas), sin perjuicio de la cesión de su aprovechamiento». 
Igualmente, y con relación a las previsiones del artículo 1 del PDS precisará que tienen un «mero carácter enunciativo y que será el resto del articulado el que concrete las prioridades, no puede el recurrente indicar cuales deben ser las prioridades y finalidades del Plan ya que precisamente ello es una facultad exclusiva del planificador, en este caso la Comunidad Autónoma que ha de fijar aquellos criterios y parámetros que considere prioritarios. Precisamente esto es planificar. Cuestión distinta es que al recurrente, como titular de canteras tenga otras prioridades que no coincidan con las del planificador y que por tanto discrepe de las mismas, pero una vez admitida la competencia del planificador, nada impide que se prefieran criterios medioambientales sobre los de explotación libre e indiscriminada».

A mayor abundamiento, la sentencia n. $^{\circ}$ 241/2003, de 21 de marzo de 2003, perfilará el objetivo de conjugar la planificación de una actividad de explotación de recursos con la necesaria protección medioambiental en los siguientes términos:

\footnotetext{
«...una de las singularidades de la Revisión del Plan es la de establecer una regulación «de forma que las canteras ocasionen un menor impacto ambiental» (art. $1^{\circ}$ ). Para ello se establecen unos criterios generales que en la aplicación al caso concreto en unos casos supondrá la apertura de la cantera y en otros no. La indicación de cuáles deben ser las prioridades y finalidades del Plan es una facultad exclusiva del planificador, en este caso la Comunidad Autónoma que ha de fijar aquellos criterios y parámetros que considere prioritarios. Precisamente esto es planificar».
}

Para el Tribunal, la visión general es la que debe inspirar el Plan, aunque no se niegue que la explotación de canteras pueda causar problemas medioambientales «no puede olvidarse que este criterio determinaría el cierre de prácticamente todas las canteras en un territorio particularmente denso y limitado como el insular, por lo que precisamente el Plan establece una serie de priorizaciones de conjunto». Por otra parte dirá igualmente que «no puede olvidarse que nos encontramos con "suelo rústico" y el destino esencial y propio del mismo lo es el uso y explotación de los recursos naturales (art. 3.1 ${ }^{\circ}$ de la Ley 6/1997, de 8 de julio, de Suelo Rústico de las Illes Balears), de modo que lo excepcional en el mismo lo es uso destinado a viviendas» y por ello resultará que «la explotación de los recursos naturales es el destino propio del suelo rústico y el destino para vivienda es el excepcional, de tal modo que es difícil analizar la cuestión desde la perspectiva de que lo prioritario debe ser la defensa de los derechos urbanísticos implantados o a establecer». En definitiva, para el TSJIB «aun con la vista puesta siempre en causar el menor impacto ambiental posible, la protección del mismo no puede impedir las necesidades racionales inherentes a un desarrollo equilibrado y, en concreto, la utilización de todos los recursos naturales». 
Creemos oportuno realizar una matización a las alusiones que realiza el TSJIB sobre el control medioambiental de las previsiones del plan. Aclaración dirigida en el sentido de que estas medidas preventivas debieran entenderse desde la perspectiva de compatibilizar la utilización racional de un recurso del suelo rústico con su explotación equilibrada en el medio. Dicho de otra forma, estableciendo una interacción entre los instrumentos de ordenación territoriales y urbanísticos con el principio de protección ambiental y paisajística, y no tanto desde la perspectiva de modificación de normas sectoriales de orden medioambiental.

A priori, no existiría ningún obstáculo insalvable para entender que las anteriores son finalidades perfectamente incardinables en los preceptos reguladores del contenido de los PDS en las respectivas Leyes de Ordenación Territorial de nuestra comunidad autónoma. Sin embargo, el establecimiento de medidas de control medioambiental, debería partir únicamente de la remisión del plan de ordenación territorial a las que pudieran haberse establecido en normativa estatal o autonómica, dictada esta última en ejercicio de la competencia de desarrollo y ejecución en materia de medio ambiente. De otra forma, en la medida en que las determinaciones de control «medioambiental» se creen en el propio plan, fuera del margen de habilitación previsto para estos instrumentos, surgirán problemas de interacción que a posteriori derivaran en consecuencias importantes.

\section{Catalogación de las actividades existentes}

Desde la vertiente de ordenación territorial, las disposiciones del PDS se concretan en los capítulos segundo y tercero del anexo normativo, con utilización de una técnica defectuosa que se concreta en las respectivas alusiones a la ubicación y al catálogo de canteras. Dicha deficiencia normativa se manifiesta ya en el propio enunciado de los capítulos alusivos a la «ubicación y catálogo de canteras» -capítulo segundo-, reiterándose en el capítulo tercero la denominación «de la ubicación de canteras». Apuntado este aspecto puramente anecdótico, podemos decir que la regulación efectuada podría encontrar amparo, con algunas matizaciones, en el título de intervención autonómico de ordenación territorial. Veamos pues a continuación el modelo territorial escogido en la regulación de estas actividades extractivas.

El artículo 4 partirá de una técnica de clasificación de las canteras previstas en el PDS que se instrumenta mediante un catálogo, que a su vez se integrará en la Dirección General de Ordenación del Territorio y Urbanismo y que incluirá los siguientes anexos: 
LA PLANIFICACIÓN TERRITORIAL DE LAS ACTIVIDADES EXTRACTIVAS: COMENTARIO CRÍTICO...

«1. Canteras activas, las que se detallan en el anexo $n .^{\circ} 1$ del Plan.

«2. Canteras incorporadas al Plan Director Sectorial, las incluidas en el anexo $n^{\circ} 2$.

«3. Canteras en tramitación para su adaptación al Plan las que se relacionan en el anexo $n^{\circ} 3$.

«4. Canteras que no han tramitado su adaptación al Plan las que se incluyen en el anexo $n .^{\circ} 4$.

«5. Canteras inactivas, las que constan en el anexo $n .^{\circ} 5$

«Las Canteras de interés etnológico definidas en el artículo 6 de este Plan se relacionan, independientemente del catálogo mencionado, en el anexo $n .^{\circ} 7 »$.

La técnica de catalogación se complementará con el mandato establecido en el artículo 5 en virtud del cual, y con la finalidad de que los datos del Catálogo de Canteras relativos a la situación de estas estén permanentemente actualizados, se establece la obligatoriedad de que la Dirección General de Industria notifique a la Dirección General de Ordenación del Territorio y Urbanismo tanto las altas y bajas que se produzcan como los cambios en la clasificación de las canteras. Este precepto pone de relieve la constatación de distintos títulos de intervención presentes en el Decreto aprobatorio del Plan puesto que, de facto, la Administración Territorial conformará en definitiva un modelo de plan que atribuye competencia al órgano que gestiona la competencia minera -Dirección General de Industria-, para el mantenimiento de un catálogo cuya actualización surtirá efectos en el ámbito de la ordenación territorial. En cualquier caso, no se aprecian en este aspecto concreto posibles excesos en la técnica de remisión, al no producirse innovación normativa en materia ajena al ámbito de actuación del planificador.

Finalmente el último de los preceptos incluidos en el capítulo segundo, el artículo 6, regulará la figura de las denominadas canteras de interés etnológico en los siguientes términos:

«Teniendo en cuenta la importancia histórica para el estudio de las costumbres y las culturas de estas canteras relacionadas en el anexo $n .^{\circ} 7$, se establece una regulación especial:

»1. Estas canteras podrán adquirir la condición de BIC (Bien de Interés Cultural) de acuerdo con su legislación específica.

"2. La rehabilitación, conservación, usos y actividades diferentes a las extractivas del resto de canteras podrá autorizarse por el ayuntamiento respectivo, previo informe de la Dirección General de Ordenación del Territorio y Urbanismo, siempre que el uso no vaya en contra de su conservación.

»3. Excepcionalmente, los ayuntamientos, en su catálogo de patrimonio histórico o similar, podrán efectuar la declaración de «canteras activas de interés etnológico», siempre que la autoridad competente en materia de minas declare compatible dicho uso». 
Se manifiesta en este sentido y tal como hemos anticipado, la aparición de un título de intervención adicional no expresamente invocado en la exposición de motivos del Decreto de aprobación del PDS, como es el relativo al patrimonio histórico y cultural de interés de la CAIB, materia sobre la que se ostenta competencia exclusiva en virtud de lo previsto en el artículo 10.21 del EA.

En ejercicio de dicha competencia se dictan en nuestra comunidad dos normas de rango legal, concretamente la Ley 12/1998, de 21 de diciembre, de Patrimonio Histórico de las Illes Balears y la Ley 1/2002, de 19 de marzo, de Cultura Popular y Tradicional. La primera de las disposiciones, al regular la categoría de Bienes de Interés Cultural, entre otras, establece las tipologías de sitio histórico y lugar de interés etnológico; mientras que la segunda dispone en su artículo 4 una concreción del concepto de patrimonio etnológico previsto en la primera, atribuyendo tal condición a los lugares y bienes muebles e inmuebles, como igualmente a bienes inmateriales: conocimientos y actividades que son o han sido expresión relevante de la cultura tradicional del pueblo de las Illes Balears en los aspectos materiales, económicos, sociales o espirituales.

Así pues, no se observa en este aspecto una extralimitación competencial en las previsiones efectuadas por el artículo 6 del PDS puesto que en realidad realiza una concreción de las normas de rango legal apuntadas para que, en determinadas circunstancias, una cantera pueda ser un elemento incardinable en las categorías de protección cultural. La única cuestión que se nos plantea es si un PDS es el instrumento idóneo para llevar a cabo esta concreción si atendemos a la definición que de él han efectuado las leyes de ordenación territorial, en los términos más arriba expuestos.

Tal vez la duda se disipe en el marco de las funciones que a los instrumentos de ordenación territorial se asigna por la legislación vigente, partiendo de la base de que los PDS necesariamente deben articularse con las previsiones de los planes territoriales insulares ${ }^{4}$, pudiendo señalar estos últimos lugares de interés histórico artístico con indicación de las medidas protectoras que deban adoptarse $\mathrm{e}^{5}$. Desde la anterior perspectiva, entendemos que no debe existir ningún obstáculo en aprovechar la tarea de catalogación previa efectuada por el PDS, más aún cuando el nuevo

\footnotetext{
${ }^{4}$ Dispone el artículo 12 de la LOT/2000 en su apartado c, que los PDS deberán prever su «articulación con los planes territoriales insulares y con el planeamiento municipal existente, con determinación expresa de las vinculaciones que se creen».

${ }^{5}$ Así lo dispone en referencia a los planes territoriales el artículo 9, apartado c) de la LOT/2000.
} 
marco legislativo derivado de la Ley 2/2001 ha comportado la atribución de la competencia para la elaboración de ambos instrumentos de ordenación territorial a los consells insulares.

Se debería en cualquier caso matizar alguna previsión efectuada en el plan director a la hora de configurar el régimen de las canteras de interés etnológico. En concreto, la previsión de rehabilitación, conservación, usos $\mathrm{y}$ actividades diferentes a las extractivas en las canteras no declaradas BIC, mediante autorización del ayuntamiento respectivo, y previo informe de la Dirección General de Ordenación del Territorio y Urbanismo, siempre que el uso no vaya en contra de su conservación, se debería complementar a nuestro entender obligatoriamente con otras prescripciones: la autorización adicional de la Administración competente en materia de Patrimonio Histórico, puesto que el hecho de no estar formalmente incluidas en la categoría de bienes de interés cultural no obsta a que por su carácter de patrimonio etnológico deba concurrir su intervención en el pertinente expediente de autorización; e igualmente la adecuación al régimen de usos del suelo rústico en el marco de su legislación reguladora que exigirá, caso de ser viable, la autorización urbanística de declaración de interés general del correspondiente consell insular con carácter previo a la licencia municipal.

Más problemática resulta la interpretación del apartado tercero del artículo 6, partiendo de la dificultad que supone la inexistencia de una definición del concepto de «cantera de interés etnológico». Efectivamente, el artículo 3 del PDS omite cualquier alusión a esta categoría en la relación de definiciones conceptuales que efectúa, añadiéndose después que el artículo 4 remitirá a una supuesta definición de cantera de interés etnológico que se prevé en el artículo 6 que, irónicamente, omite cualquier alusión.

Dispone el citado apartado 3 que, «excepcionalmente, los ayuntamientos, en su catálogo de patrimonio histórico o similar, podrán efectuar la declaración de "canteras activas de interés etnológico», siempre que la autoridad competente en materia de minas declare compatible dicho uso». Se produce inevitablemente una confusión al aplicador del Plan: ¿A que canteras se refiere esa declaración potencial de «activas de interés etnológico? Debemos suponer, por exclusión, que sólo puede hacer referencia a las incluidas en el anexo 1 del Plan (canteras activas), pero que no se relacionen en el anexo 7 (canteras de interés etnológico), a las que el ayuntamiento atribuirá por catalogación municipal la condición de interés etnológico, previa su «declaración de compatibilidad de uso» a efectuar por parte de la administración minera. Esta última declaración, impropiamente se establece con referencia al uso, pero en realidad, y de acuerdo con la 
confusa sistemática, sólo puede referirse a la declaración municipal de interés etnológico, si partimos de la base que el uso activo es la actividad extractiva.

Apuntamos llegados a este punto un rasgo característico de la regulación establecida en los artículos comprensivos del capítulo segundo del PDS, como será el componente «estático» en la posibilidad de autorización de explotaciones. Se parte así de la catalogación de una serie de canteras que, con independencia de su situación (activas, incorporadas, en tramitación...), se encontrarán relacionadas exhaustivamente en los anexos 1 a 7 del Plan, constituyéndose esta característica, en un principio, en la regla general y que únicamente se verá exceptuada en el capítulo tercero, que se constituye en la norma especial que posibilita la autorización de nuevas canteras no incluidas en los anteriores catálogos.

La anterior técnica de inventario y catalogación, establecida $a b$ initio como norma general por parte del PDS, resulta avalada plenamente por parte del TSJIB. Así, en sus sentencias n. ${ }^{\circ} 372 / 2001$, de 3 de abril de 2001, y 241/2003, de 21 de marzo de 2003, establece que «la inclusión en el Plan como zona extractiva de aquellas canteras que disponían de previa autorización, tal como se señalaba en la Memoria y documentación del Plan, venía justificada precisamente por la indicada autorización. Tanto el Plan, como la revisión de que aquí se trata, parten de la situación técnica y administrativa de cada cantera. Con ese punto de partida, a la vista de las necesidades globales se fija la ubicación que, en general, coincide con las canteras previamente autorizadas o en trámite para la obtención de alguna licencia o autorización concurrente.../... El Plan Director Sectorial de Canteras se regía pues por la inclusión de las que ya dispusieran de previa autorización, de modo que la inclusión de las del caso, pese a lo que se sostiene en la demanda, no sólo es que no represente que la revisión se aparte de los principios rectores del Plan sino que, precisamente, se ajusta a los mismos».

Problemática distinta va a ofrecer la regla de excepción a la norma general, que posibilita la ubicación de nuevas canteras que previamente no hayan sido inventariadas o catalogadas, que pasamos a analizar a continuación.

\section{Ubicación de nuevas canteras}

El capítulo tercero del PDS, como se ha avanzado, establece el régimen aplicable en lo relativo a la posible ubicación territorial de nuevas cante- 
ras fuera de las que han sido objeto de previa catalogación, fijando a la vez determinados criterios de preferencia para su autorización. Se contemplan en el artículo 7, en su apartado primero, las siguientes determinaciones sobre el particular:

«1. La Dirección General de Industria tan sólo podrá autorizar la ubicación de nuevas canteras en las zonas de localización de recursos de interés minero, señaladas en los planos que figuran como anexo $n .^{\circ} 8$ de este Plan. Se exceptúan los casos tanto de ampliación de una cantera activa como los de autorización en otras zonas, en casos excepcionales, previa declaración de interés público o de interés general por el Consell de Govern de la Comunitat Autónoma».

De la lectura del anterior apartado se desprenden las siguientes notas características:

1. Establecimiento por parte del instrumento de ordenación territorial de una vinculación derivada de ese ámbito del ordenamiento jurídico para la Administración sectorial minera, en lo que se refiere a posibles ubicaciones físicas de nuevas actividades de explotación de recursos, bajo el amparo del objetivo y determinaciones del plan contempladas hoy en los artículos 11 y 12 de la LOT/2000, que condicionarán -como norma general- las posibles autorizaciones de la Dirección General de Industria desde su ámbito sectorial de intervención únicamente en cuanto se localizasen en zonas de interés minero previamente definidas en la documentación planimétrica que conforma el anexo 8 del plan director al que se hace alusión.

Con una nefasta redacción, el artículo 8 determinará unos criterios de prioridad para la ubicación de nuevas canteras en los siguientes términos:

"Cuando a juicio de la Dirección General de Industria, oídas las asociaciones empresariales representantes del sector, la demanda existente en cada isla, o en una zona de Mallorca, determine la conveniencia de nuevas canteras, para su autorización, la persona interesada deberá considerar los siguientes criterios de prioridad:

$» 1^{\circ}$. La ampliación de canteras activas.

$" 2^{\circ}$. La reexplotación de canteras inactivas.

$» 3^{\circ}$. La posibilidad de recurrir a la sustitución de un material por otro.

»En todos los casos se tendrá en cuenta la idoneidad de los accesos de la cantera para el tráfico que genere la actividad extractiva».

Como se puede ver los términos literales son más bien poco afortunados. Para la correcta aplicación de los «criterios de prioridad a considerar» no queda más remedio que proceder a su interpretación en sentido contrario, puesto que de otra manera no se entendería su articulación. 
Deducimos que para autorizar excepcionalmente una nueva cantera, se deberá iniciar un procedimiento a instancia de parte (persona interesada, expresa literalmente el citado artículo), en el que deberá acreditarse la necesidad de apertura de una nueva cantera no prevista en los catálogos del plan por imposibilidad de proceder a la ampliación de canteras ya en actividad o en su caso de llevar a cabo la reexplotación de las inactivas. En consecuencia, los apuntados no son en si mismos «criterios de priorización» sino más bien cuestiones previas a justificar para dar trámite a la solicitud.

El tercer criterio, supuesto el relativo a la sustitución de material, se escapa a cualquier intento de comprensión desde el propio precepto si no indagamos en la memoria del PDS para determinar el alcance de esta inconcreta cláusula. Se efectúa en aquel documento un «estudio de posibles sustituciones entre recursos», introduciendo una sistemática de catalogación de los distintos tipos de materiales, a los que se asignan hasta siete grados o niveles de sustitución. Las alternativas, aparte de referirse estrictamente a la compatibilidad para usos de distintos materiales, se deben ligar en lo que pretende ser el objeto del PDS también a la preexistencia de yacimientos que exploten un producto con un determinado grado de compatibilidad o de identidad de material al que pretende ser explotado con la apertura de una nueva cantera.

Por tanto, una vez más se manifiesta la deficiente técnica del planificador, que no concreta en la parte normativa del PDS, aunque sea resumidamente, los criterios de priorización, debiendo acudir a tal efecto a un documento del plan que no tiene carácter normativo contribuyendo todo ello a debilitar la eficacia de sus determinaciones. La cuestión se podría haber resuelto con la introducción de una redacción similar a «valoración de la existencia de posibles sustituciones del material a extraer en la nueva cantera por la producción de otras preexistentes explotadoras del mismo producto o de otro compatible con los usos a los que se pretende destinar el primero, de acuerdo con los criterios establecidos en el anexo...», complementándose con la adición de un pequeño anexo normativo que definiese dichas pautas.

Contrariamente dicha imprecisión contribuye a que se presente a nuestro entender, y de la lectura del anterior artículo, un único criterio de priorización para la conveniencia de nuevas canteras, previa constatación de la existencia de las tres anteriores circunstancias de viabilidad de la petición, como será la idoneidad de los accesos a la nueva cantera propuesta ${ }^{6}$.

\footnotetext{
${ }^{6}$ La sentencia del TSJIB n. ${ }^{\circ}$ 241/2003, de 21 de marzo de 2003, aclararía que dicho criterio de prioridad se refiere exclusivamente a la apertura de nuevas canteras, no siendo aplicable a las autoriza-
} 
Ello provocará una excesiva discrecionalidad debido a que la decisión administrativa excepcional se adoptará sin unos criterios claros en orden a las nuevas ubicaciones, salvo que se quiera interpretar teleológicamente, más que literalmente, el criticado artículo 8 del Plan.

2. Se crea a su vez en un régimen ya de por sí singular, una segunda norma excepcional para los casos de ampliaciones de canteras activas fuera de las zonas habilitadas en el anexo 8 del PDS. A sensu contrario la previsión posibilitaría la autorización de ampliaciones en canteras activas que estuviesen ubicadas fuera de las zonas habilitadas por el anexo 8, pero recogidas en el anexo 1.

3. En el mismo proceso de excepcionalidad aún se recogerá una tercera situación de excepción en el régimen singular, como es la posibilidad de que por declaración expresa por parte del Consell de Govern de la Comunidad Autónoma, mediante declaración de interés público o de interés general se pueda autorizar la ubicación de una nueva cantera en otras zonas aún no previstas en el anexo 8. Dicha norma de excepción no estará exenta de problemas de legalidad puesto que, como mínimo, se detectan en ella las siguientes patologías - predicables, aunque en menor grado, igualmente de todas las situaciones previstas en el artículo 7 del PDS sobre ubicación de nuevas actividades extractivas-:

a) Se vulnera claramente el principio de necesaria concreción en el plan relativo a la «relación y localización de las obras y actuaciones integradas en el plan» -artículos 12.f) de la LOT/2000 y 22.f) de la LOT/1987-,

das en el momento de la aprobación del PDS: «El art. 8, al establecer criterios de prioridad para la ubicación de nuevas canteras, indica que «se tendrá en cuenta la idoneidad de los accesos de la cantera para el tráfico que genere la actividad extractiva». Lo dudoso es dicha previsión afecte a las canteras de Son Corp y Son Corpet, ya que el precepto viene referido a la ubicación de nuevas canteras, esto es, para el caso de autorización de nuevas canteras, mientras que las dos canteras referidas, no debe olvidarse que ya son canteras previamente autorizadas y que por tanto no serían «nuevas canteras» objeto de apertura.

«En definitiva, poco importa la idoneidad de los accesos y las pruebas practicadas al respecto en la medida en que el art. 7 y 8 de la Revisión del Plan no afecta a las canteras ya autorizadas. De la lectura del art. 7 se desprende que la expresión «apertura de nuevas canteras» no viene referido al sentido literal de inicio de actividad extractiva, sino a la autorización de nuevas canteras (ver pfo. $2^{\circ} \mathrm{del}$ art. 7). En consecuencia, las canteras ya autorizadas son canteras activas, incorporadas al Plan o en tramitación para adaptación al Plan (art. 3), pero no «nuevas canteras».

«Como bien se indica en la propia demanda, la discusión relativa a la idoneidad de los accesos podrá ser motivo de impugnación de las autorizaciones concedidas en su día, pero no para discutir la inclusión de tales canteras en el «catálogo de canteras incorporadas al PDS de Canteras» ya que para ello basta constatar que son canteras que al tiempo de aprobarse el Plan disponían de autorización o concesión minera e informe favorable de la CBMA o de la Dirección General de Ordenació del Territori». 
habilitándose así, a una modificación de facto del plan mediante acuerdos singulares adoptados fuera de los márgenes procedimentales que fija la LOT para su aprobación y modificación.

b) Indefinición conceptual de los títulos de intervención sectorial de las declaraciones de «interés público»e «interés general» a los que alude la norma.

c) Al hilo del aspecto anterior, posible infracción manifiesta del artículo 37 de la Ley 6/1997, del Suelo Rústico, con relación a la Ley 9/1990, de 27 de junio, de atribución de competencias a los consells insulares en materia de urbanismo, si se pretende hacer alusión a la declaración urbanística de interés general, en principio única técnica posible o válida para dar cobertura a un uso extractivo del suelo rústico fuera de los márgenes del PDS.

d) Situación de inseguridad jurídica a la hora de calibrar el mantenimiento de la potestad excepcional en el Consell de Govern de la CCAA, tras el proceso de transferencia de la competencia para la elaboración del PDS de Canteras a los consells insulars en virtud de la Ley 2/2001 aludida inicialmente.

En cualquier caso, el apartado segundo del artículo 7 del PDS definirá una norma de aplicación directa e indisponible, que no podrá ser neutralizada por los actos de autorización excepcional derivados del apartado primero anterior. En este sentido, se contempla que:

«2. No se podrán autorizar nuevas canteras en el ámbito de las Áreas de Especial Protección de interés para la Comunidad Autónoma de las Illes Balears delimitadas por la Ley 1/1991, de 30 de enero, de Espacios Naturales y de Régimen Urbanístico, modificada por la Ley 7/1992, de 23 de diciembre.

»Tampoco se permitirán extracciones de arena, ni el mantenimiento de las existentes:

»a) En el ámbito de las ANEI (Áreas Naturales de Especial Interés) declaradas por la mencionada Ley.

»b) En los sistemas dunares litorales delimitados en el mapa geológico de España, elaborado por el Instituto Tecnológico Geominero de España (escala 1:50.000 ó 1:25.000)».

Aún a pesar de la claridad de los términos, merecen realizarse algunas puntualizaciones. Se parte del establecimiento de normas prohibitivas con relación al objeto de regulación material del plan, las canteras, pero se aprovecha para fijar una norma de ordenación territorial que impide realizar un tipo concreto de actividad extractiva de arena en los ámbitos y sistemas relacionados más arriba, tratándose esta segunda previsión de una norma autoejecutiva del PDS con vinculación directa 
al planificador municipal y al gestor de las actividades a realizar en este tipo de suelo.

Vinculación la anterior que se introduce directamente por el plan puesto que como veremos seguidamente, a diferencia de la regulación de las canteras en las zonas ANEI, no existía norma supramunicipal que regulase en dichas áreas la imposibilidad de realizar extracciones de arena, salvo bajo la cláusula generalista prevista en el artículo 7 de la Ley 1/1991, de 30 de enero, de Espacios Naturales y de Régimen Urbanístico de las Áreas de Especial Protección (LEN) que impedía utilizaciones que implicasen transformación del destino y naturaleza de las áreas o que pudieran lesionar sus valores ecológicos o paisajísticos.

Sin embargo, el artículo 7.2 del PDS no solventa directamente la duda respecto a la posibilidad o imposibilidad de autorizar ampliaciones de canteras existentes en el ámbito de las áreas de especial protección definidas en la LEN 7 . Una primera lectura del número 1 del artículo 7 del PDS pudiera hacer pensar en tal posibilidad si se quiere partir de la idea de que su número 2 prohíbe expresamente la autorización de nuevas canteras en dichos ámbitos, pero no la ampliación de las existentes, que podrían así acogerse a la cláusula prevista con carácter general.

Pero a nuestro entender, debe rechazarse dicha posible interpretación, si atendemos a la existencia de una norma de rango legal fijada en la propia LEN que establece un mandato directo al PDS. Concretamente nos referimos a su artículo 22, que sobre el particular contempla:

«1. En las Áreas de Especial Protección no se permitirá la obertura de nuevas canteras a no ser en casos excepcionales en que por motivos de interés público, así lo prevea en un lugar determinado el Plan Director Sectorial de Canteras.

"2. Sin perjuicio de lo establecido en el apartado anterior, las canteras existentes a la entrada en vigor de la presente Ley podrán mantener su explotación con las limitaciones que determine el citado Plan. La obligatoriedad de los planes de restauración afectará a todas las canteras abiertas en las Áreas en toda su extensión».

En este punto, entendemos que el PDS se limita a recoger el mandato legal prohibitivo establecido en el artículo 22.1 de la LEN, aplicable a todas las áreas de especial protección ${ }^{8}$ (ANEI y ARIP). En definitiva,

\footnotetext{
${ }^{7}$ En lo que ahora nos interesa, la citada Ley crea dos categorías de suelo rústico protegido: las Áreas Naturales de Especial Interés (ANEI) y las Áreas Rurales de Interés Paisajístico (ARIP).

8 A diferencia de la prohibición de actividad extractiva de arena, que se circunscribe a las áreas declaradas ANEI.
} 
recoge el mandato general y legal de prohibición de nuevas canteras en dichas zonas protegidas ex lege, sin que tampoco el planificador haga uso de la opción de señalar excepcionalmente posibles nuevas explotaciones por motivos de interés público.

Respecto a la posible explotación de las canteras existentes a la entrada en vigor de la referida LEN, es importante traer a colación una sentencia del TSJIB aclaratoria de las posibilidades que ofrece esta previsión, así la $\mathrm{n}^{\circ} .993 / 2002$, de 3 de diciembre de 2002 ha venido a establecer inequívocamente la imposibilidad de regularizar, mediante su incorporación al Plan como canteras activas, de aquellas instalaciones ubicadas en áreas de especial protección que hubieren obtenido su autorización con posterioridad a la expresada entrada en vigor de la norma legal de protección.

Aunque la LEN no impide la explotación de las canteras existentes, ha obviado el planificador el cumplimiento del mandato establecido en su artículo 22.2, que como hemos podido ver ordena la imposición de limitaciones específicas. Ello sirve para poner de manifiesto que si la Ley imponía el establecimiento de restricciones concretas en las explotaciones extractivas existentes, con mayor razón el PDS debería haber recogido expresamente mediante norma ad hoc la posibilidad de ampliaciones, no siendo por tanto aplicable la cláusula general prevista en el artículo 7.1, que debemos entender referido a las instalaciones ubicadas fuera de las zonas afectadas por la LEN 9 .

En cualquier caso, debemos apuntar la existencia de una disposición adicional en el PDS que definitivamente aclara la cuestión, aún sin establecer unas limitaciones específicas para el mantenimiento de la explotación (que a nuestro entender se pensaban por el legislador en el establecimiento de condiciones más restrictivas en cuanto al mismo funcionamiento), introduciendo la norma según la cual -disposición adicional segunda- «las canteras ubicadas dentro de las Áreas de Especial Protección, tendrán como ámbito máximo de explotación el contenido en su autorización minera»; leída en sentido contrario, se desprende claramente que no serán así posibles hipotéticas ampliaciones de su ámbito de ocupación territoria $1^{10}$.

\footnotetext{
9 Sirva en cualquier caso el artículo 22 de la LEN para poner de manifiesto la ilegalidad de las previsiones del PDS antes apuntadas y que permiten la implantación en el resto de zonas de nuevas canteras, no recogidas singularizadamente en sus anexos, mediante acto administrativo singular de la dirección general de Industria o del Consell de Govern, ya que como aclara la LEN en su régimen específico, la excepción se debe realizar en su caso por parte del propio Plan Director, y no por remisión a posteriores actos administrativos singulares.

10 Aún así, y siempre en la constante introducción de excepciones, la disposición adicional primera dispondrá un régimen específico para dos canteras, a las que incluso se dedica un anexo del plan en exclusiva.
} 


\section{Cobertura legal de las determinaciones territoriales del PDS}

Con independencia de las críticas personales a algunos aspectos de los regímenes excepcionales y de deficiencia en la técnica normativa, llegados a este punto, con carácter general y desde la perspectiva reguladora del plan hasta ahora expuesta, no observamos ningún exceso evidente o extralimitación del planificador, en los términos de delimitación de su ámbito de intervención que viene a aclarar la sentencia del TSJIB $\mathrm{n}^{\circ}$ 280/2001, de 9 de marzo de 2001, dictada con motivo de la impugnación de la revisión del PDS que ahora nos ocupa.

Considera así el Tribunal que «la planificación y ordenación de la actividad extractiva, con la evidente incidencia territorial que esta comporta, requiere priorizar y determinar tanto en que puntos se permitirá dicha actividad como aquellos en que ha de prohibirse. Pues bien, en ese sentido, el ejercicio de la facultad de planificación puede llevarse a cabo tanto mediante el establecimiento de zonas como a través de señalar las características o circunstancias generales identificativas...»

Delimitado pues el alcance e incidencia de la regulación en materia de ordenación territorial, debemos analizar en que medida el resto de disposiciones podrán encajar en el citado ámbito de habilitación del planificador. Ante la ausencia de jurisprudencia relativa a este punto, deberemos acudir para ello a otros referentes previos que hayan podido tratar aspectos similares en otros planes directores. Ha sido este el caso del PDS de Equipamientos Comerciales, objeto igualmente de enjuiciamiento por parte del TSJIB, cuya interferencia con el título competencial en materia de comercio interior se ventila en su sentencia $n$. $^{\circ} 27 / 2002$, de 8 de enero de 2002, en los siguientes términos:

«Pues bien, ocurre que el Decreto 217/1996, de 12 de diciembre, por el que se aprobaba definitivamente el Plan Director Sectorial de Equipamientos Comerciales de las Islas Baleares, arranca de la competencia exclusiva en materia de ordenación del Territorio - artículo 10.3 del Estatuto de Autonomía- por lo que se apoya en la Ley 8/1987, de 1 de abril, de Ordenación Territorial de las Illes Balears.

»Las definiciones que el Plan contiene sobre la actividad comercial o respecto a local o establecimiento dedicado al comercio, gran superficie, etc., lo son con función identificativa y a los efectos del propio Plan, señalándose así en el mismo.

»Por tanto, cualquier diferencia que pueda observarse en relación a la Ley 7/1996 carece de trascendencia. 
„El Plan-artículo 12- no somete a autorización previa la actividad comercial sino la construcción de las edificaciones de equipamientos comerciales, de modo que los criterios que para dicha autorización contempla el Plan no tienen por qué coincidir con los que se contienen en el artículo 6 de la Ley 7/1996 para la licencia comercial, como tampoco el régimen del silencio».

Aún partiendo de que la consideración anterior del TSJIB se realiza bajo el prisma de la posible incidencia de un título competencial sobre comercio interior no atribuido a la CAIB, confirmando la regulación desde la óptica territorial del PDS, entendemos que mutatis mutandi nos sirve para perfilar el alcance que debe asignarse a las determinaciones de un instrumento de ordenación territorial en la medida que pueda incidir en otros títulos competenciales de la CAIB no derivados de la ordenación del territorio y el urbanismo.

Deducimos que mediante un plan territorial no seria posible producir innovación en normativas cuya elaboración derivase de títulos habilitantes distintos del previsto en el artículo 10.3 del Estatuto de Autonomía, si bien seria perfectamente posible introducir determinadas previsiones a efectos «identificativos» y para la aplicación del propio plan. A sensu contrario confirmarían la anterior posición las sentencias del TSJIB $\mathrm{n}^{\circ}$ 241/2003, de 21 de marzo de 2003, y n. ${ }^{\circ} 457 / 2003$, de 29 de mayo de 2003, en las que se afirma:

«Se alega que la Revisión del PDSC omite fijar criterios de distancias mínimas entre canteras y viviendas, cuando el art. 3 del Decreto 2857/1978, de 25 de agosto, si las fija.

"No obstante, un Plan Director Sectorial - como en este caso el de canterasno tiene por objeto la regulación completa y exhaustiva de la materia, sino antes al contrario fijar unos criterios básicos para la definición de ubicación de las canteras en las distintas zonas de la isla, pero la fijación de distancias mínimas entre canteras y viviendas no constituye contenido necesario del Plan Sectorial.

„La normativa que regula tales cuestiones lo es la Ley de Minas y los Reglamentos Generales de Régimen de la Minería y de Normas Básicas de Seguridad Minera, sin que el Plan Director, que complemente dicha normativa desde la perspectiva de la ordenación territorial, deba regular aspectos singularizados de dicha explotación».

Dicho de otra manera, se podría entender que el PDS puede efectuar una regulación de complemento de normativa sectorial en que la CAIB ostente habilitación, pero siempre desde la consideración de que los aspectos singularizados que se regulen se dicten desde la citada perspectiva de la ordenación del territorio, pero no desde la perspectiva de una modificación expresa de la regulación sectorial existente y procedente de otros títulos. En este sentido, la referida sentencia alude a que la finalidad protectora del 
medio ambiente -título competencial diferente de la ordenación territorial- se canaliza estableciendo criterios que compatibilicen la necesaria explotación de tales recursos con la priorización de aquellas formas de explotación y ubicaciones menos dañinas; en consecuencia partiendo de las necesidades globales se fija la ubicación de dichas actividades.

\section{LOS PLANES DE RESTAURACIÓN. SU PROBLEMÁTICA INCARDINACIÓN EN EL PDS}

El capítulo cuarto del PDS, bajo el título «de los planes de restauración y su tramitación», efectúa la regulación de esa figura pero sin que se pueda hablar de una articulación con las disposiciones de ordenación territorial de la actividad extractiva. Antes al contrario, sus determinaciones conectarán de forma directa con las autorizaciones sectoriales mineras, en definitiva, se constituye en complemento de normativa reglamentaria ajena a las determinaciones propias de un instrumento de ordenación del territorio, factor que como veremos supone la mayor problemática estructurante del plan director que comportará una serie de distorsiones.

Ciertamente podremos constatar que la figura del plan de restauración se ligará estrictamente con la intervención de la Administración minera, título al que se le atribuirá impropiamente algunos importantes efectos con relación al planeamiento urbanístico municipal y que se producirán incluso fuera de los márgenes de las propias determinaciones de ordenación territorial del PDS. Todo ello partirá, como hemos avanzado, de que en definitiva buena parte de la regulación material contemplada en su capítulo cuarto en ningún caso puede considerarse como manifestación de técnicas de planificación de la ordenación del territorio, sino contrariamente una manifestación del ejercicio de la potestad reglamentaria estricto sensu en materia ajena a la planificación territorial o urbanística, que deriva de los otros dos títulos habilitantes invocados por el propio redactor del plan: medio ambiente y régimen minero.

El artículo 10 entiende así por Plan de Restauración «el conjunto de medidas que tienen que adoptar los titulares de la autorización o concesión minera, para que el espacio natural afectado por las labores extractivas recupere sus características originales o llegue a conseguir su integración medioambiental y paisajística». La anterior definición viene a positivizar de alguna manera el concepto de Plan de Restauración que se deduce de la lectura de las determinaciones del Real Decreto 2294/1982, de 15 de octubre, al que efectúa constantemente remisión expresa el PDS. 
A continuación, se introduce en el artículo 11 una determinación absolutamente inocua bajo la supuesta concreción de un régimen específico aplicable al Plan de Restauración para canteras ubicadas en zonas de especial protección, al disponer que «el Plan de restauración de una cantera ubicada en el ámbito de un área de Especial Protección de interés para la Comunidad autónoma deberá comprender la restauración del área afectada por la actividad extractiva, en toda su extensión, en aplicación de lo dispuesto en el artículo 22.2 de la Ley 1/1991, de 30 de enero, de Espacios Naturales y de Régimen Urbanístico de las Áreas de Especial Protección de las Illes Balears».

Verdaderamente cabe preguntarse que determinación específica acaba de introducir el planificador que no figurase ya expresamente en la norma legal transcrita más arriba; como igualmente si esta supuesta «determinación específica» no deba ser asimismo aplicable a todas las canteras, con independencia de su ubicación en áreas de especial protección: al menos así debe deducirse del contenido del Plan de Restauración que establece el artículo 3 del aludido RD 2994/1982.

Llegados a este punto, consideramos del todo necesario transcribir íntegramente el artículo 12 del PDS para centrar mejor los aspectos críticos del contenido del instrumento de ordenación. El precepto, bajo la rúbrica de «documentación y tramitación de los Planes de Restauración» contemplará:

«1. El Plan de Restauración deberá contener la documentación que exige la normativa minera, e incluirá un estudio de evaluación de impacto ambiental de acuerdo con la normativa especifica de la Comunidad Autónoma de las Illes Balears.

"2. Para la solicitud de una autorización de aprovechamiento o de una concesión de explotación, la persona interesada deberá presentar cuatro ejemplares del proyecto de plan de restauración en la Dirección General de Industria, que será sometido a información pública durante un plazo de 20 días, dando traslado al Ayuntamiento afectado para que dentro de este plazo, si lo considera oportuno, pueda emitir informe.

»Terminada la fase de exposición pública, se remitirá una copia del mencionado Plan, junto con las alegaciones presentadas y el informe del Ayuntamiento, si lo hubiere a la Comisión Balear de Medio Ambiente (CBMA), a fin de que emita informe preceptivo y vinculante en el plazo de dos meses, desde la recepción del expediente completo.

"El mencionado informe, en caso de que sea favorable, será remitido a la Dirección General de Industria para que otorgue la autorización de aprovechamiento o la concesión de explotación, circunstancia que se deberá notificar a la Dirección General de Ordenación del Territorio y Urbanismo a fin de que inscriba la cantera en la lista de las incorporadas al Plan, del Catálogo de esta Dirección General. 
LA PLANIFICACIÓN TERRITORIAL DE LAS ACTIVIDADES EXTRACTIVAS: COMENTARIO CRÍTICO...

»Previamente al otorgamiento de la autorización/concesión de explotación, el solicitante deberá designar un responsable técnico ante la Administración encargado de la ejecución del Plan de Restauración.

»El acuerdo de inclusión de la cantera en el Catálogo se comunicará a los ayuntamientos afectados, de acuerdo con lo que establece el artículo 23 de la Ley 8/1987 de Ordenación del Territorio de las Illes Balears, y se publicará en el Boletin Oficial de las Illes Balears».

Como veremos se llevará a término en la práctica un desarrollo reglamentario autonómico de la normativa estatal sobre régimen minero. Debemos partir de la constatación del hecho de que, en definitiva, el Plan de Restauración conceptuado en los artículos 10 y 11 del PDS se conforma en documentación adicional a aportar con la petición de autorización de aprovechamiento o de una concesión de explotación. Sobre este particular no se produce de hecho innovación normativa, sino que el PDS se convertiría en elemento recordatorio o coadyuvante en el cumplimiento de las determinaciones del RD 2994/1982.

La problemática normativa se manifestará a partir del momento en que a las citadas autorizaciones sustantivas de la Administración minera se les exigirá la previa incorporación de informe medioambiental favorable; obtenidas en su caso aquellas autorizaciones, la vinculación a efectos territoriales se manifestará en su comunicación a la Dirección General de Ordenación del Territorio a los efectos de inclusión en la lista de canteras incorporadas en el catálogo del PDS.

Con independencia de los posteriores efectos con relación a las determinaciones del PDS, en lo que ahora interesa resaltar de la regulación efectuada de los Planes de Restauración es en el aspecto que, finalmente, lo llevado a cabo por la CAIB fue de facto desarrollar normativa sectorial minera -ex artículo 11.10 del EA- pero fuera de los márgenes procedimentales fijados para la elaboración de disposiciones administrativas de carácter general; produciéndose a través de un procedimiento inadecuado como es el fijado en la LOT para la elaboración de planes directores sectoriales. Dicho en otras palabras, se utilizó el procedimiento de elaboración de planes de ordenación territorial previsto en la LOT para la introducción de determinaciones que, a priori, debieran haberse incardinado en el procedimiento previsto para la elaboración de normas reglamentarias entendidas en sentido estricto.

Como hemos avanzado, la anterior patología, prima facie, no tendría especial importancia si en el aspecto de regulación material no se produjese innovación sino simplemente una remisión normativa o recordatoria de lo ya previsto en norma reglamentaria vigente, en este caso el repetido 
RD 2994/1982, cuyo contenido en buena parte se transpone en el PDS. Ahora bien, la lectura detenida del artículo 12 del instrumento de ordenación territorial pone de manifiesto un exceso del planificador, como intentaremos apuntar seguidamente.

Básicamente debemos partir de la previsión de la inclusión en el Plan de Restauración de un estudio de evaluación de impacto ambiental de acuerdo con la normativa específica de la Comunidad Autónoma de las Illes Balears -Decreto 4/1986, de 23 de febrero, de implantación y regulación de los Estudios de Evaluación de Impacto Ambiental-. La inclusión del documento de evaluación dispone de cobertura en la propia reglamentación específica estatal, desde el momento en que el contenido establecido en el artículo 3 del RD 2294/1982, entre otras determinaciones exigibles al Plan contempla el estudio del impacto ambiental de la explotación sobre los recursos naturales de la zona y las medidas previstas para su protección.

Pero la concreción de la regulación procedimental para la autorización de aprovechamiento o concesión de explotación, con previsión de un período de exposición pública del Plan de Restauración y del EIA, es materia que a priori excedería del ámbito de regulación de un instrumento de ordenación territorial.

Curiosamente, la problemática podía haberse evitado simplemente obviando una regulación de procedimiento, puesto que en la práctica el efecto deseado pudiera haberse obtenido con la aplicación estricta de la normativa autonómica vigente en materia medioambiental y de las determinaciones de la LRJ-PAC.

En este sentido, ya el Decreto 4/1986, contemplaba como actuación sujeta a evaluación de impacto ambiental simplificada en su anexo III a la «2. Industria extractiva.../... 2.2. Explotaciones mineras. 2.3 Canteras» -supuesto en el que se podía perfectamente incluir el caso de su correspondiente Plan de Restauración-. Al mismo tiempo, y dado que el procedimiento sustantivo de autorización no preveía el trámite de información pública -sí exigible para la evaluación de impacto-, se debía aplicar la cláusula prevista en el artículo 8.1 del citado Decreto 4/1986, que dispone que si no fuera precisa reglamentariamente la información pública de la actuación (se omitiera la previsión de dicho trámite en el procedimiento sustantivo), el documento de síntesis de la EIA se debía someter a este trámite; en consecuencia no restaba sino acudir en estas situaciones a la norma supletoria prevista en el artículo 86 de la LRJ-PAC, que curiosamente contemplaba idéntico plazo de información pública de veinte días que el previsto en el PDS. 
De otro lado, la solicitud de informe del Ayuntamiento afectado, aún sin previsión expresa en el RD 2294/1982, era plenamente factible desde el punto de partida de su consideración de Administración municipal evidentemente con interés en el procedimiento de autorización, pudiéndosele solicitar informe facultativo ex artículo 82 de la LRJ-PAC, fundamentando la conveniencia de emisión de informe sobre las competencias municipales afectadas por la autorización sectorial autonómica, ello sin entrar a analizar si devenía exigible legalmente la aplicación del artículo 84 de la citada LRJ-PAC y, en consecuencia, ofrecer trámite de audiencia previa a la resolución al Ayuntamiento, al verse afectado por las repercusiones posteriores en sus competencias en materia de autorizaciones municipales urbanísticas o de actividad.

El informe a emitir por parte de la Comisión Balear de Medio Ambiente se configura como preceptivo y vinculante para el órgano titular de la competencia sustantiva, la Dirección General de Industria, que solamente podrá atorgar la autorización de aprovechamiento o la concesión de explotación en caso de que el informe ambiental sea favorable, tal y como expresamente dispone el artículo 12 del PDS ahora comentado. Este factor supone una modificación por vía indirecta del referido Decreto autonómico 4/1986, que en todos los supuestos sometidos a evaluación de impacto ambiental se configura al dictamen de la Comisión Balear de Medio Ambiento como preceptivo, pero no de carácter vinculante, cosa que demuestra una vez más la incorrecta vía utilizada por el planificador para la regulación de aspectos reservados a normas reglamentarias que no son instrumentos de ordenación territorial.

Se podría plantear si, una vez mas, esa regulación en definitiva tiene amparo en las normativas estatales ya reiteradas. Así, acudiendo a la disposición adicional tercera del PDS, observamos que se dispone que a efectos de lo dispuesto en el artículo 12 será de aplicación el RD 2294/1982, aclarándose en su segundo párrafo que el estudio de evaluación de impacto ambiental previsto en el artículo 3 del citado Real Decreto se expresará de acuerdo con la normativa específica de nuestra Comunidad Autónoma.

Ahora bien, constatándose efectivamente la exigencia de estudio del impacto ambiental de la explotación, y aún disponiéndose en el punto 2 del artículo 4 del RD 2294/1982 que el otorgamiento de autorizaciones no procede si a través del Plan de Restauración no queda debidamente asegurada la restauración del espacio natural, en ningún caso se regula un régimen específico de intervención de la Administración ambiental en la evaluación del estudio, y por derivación tampoco se prevé el carácter vinculante al hipotético dictamen ambiental. 
Respecto del régimen establecido en el RD 2294/1982 se ponía de manifiesto por parte de la doctrina algunas inconcreciones sobre este particular, así Pérez MARTOS ${ }^{11}$ destaca:

a) Una patente debilidad de la Administración ambiental en la imposición, control y vigilancia de las medidas del Plan de Restauración, pues la intervención de esta Administración queda reducida a la emisión de informes con carácter general y de forma específica, con carácter previo, cuando la Administración minera pretenda exigir ampliaciones o introducir modificaciones al Plan.

b) Otorgamiento de una amplia discrecionalidad a la Administración minera respecto de la facultad de solicitar informes a la Administración ambiental así como para determinar el valor de éstos.

En definitiva, el PDS complementaría la normativa estatal evitando la inconcreción y discrecionalidad apuntada, objetivo cuya bondad no se discute sino con relación al instrumento utilizado, que comporta una evidente modificación del régimen jurídico del acto administrativo de intervención de la Administración ambiental previsto en el Decreto 4/1986 en lo referente a estas actuaciones específicas. Más aún, sin ningún reparo en cuanto a la omisión del procedimiento establecido, su disposición adicional sexta opera una modificación expresa al Decreto 4/1986, en el punto 2.2 de su anexo III citado más arriba, sustituyendo la mención a «explotación minera» por la de «2.2. Autorización de aprovechamiento o concesión de explotación minera».

En el contexto impropio de modificación del Decreto 4/1986, la variación operada supone de hecho sujetar a doble intervención de la Administración autonómica ambiental la apertura de una nueva cantera, puesto que dicha actuación se mantiene como objeto de evaluación en el punto 2.3 del anexo III del Decreto ${ }^{12}$, a la vez que la paralela autorización o concesión de explotación minera.

Se traslada pues al ámbito normativo autonómico la problemática ya ocasionada en el régimen estatal que pone de manifiesto la doctrina citada más arriba con relación a determinadas actividades mineras de extracción a cielo abierto, en cuanto que las disposiciones del RD 2294/1982 no

\footnotetext{
11 J. PÉrez Martos, 2000, «Ordenación minera y medio ambiente. La intervención preventiva de las Administraciones Públicas en la explotación y aprovechamiento de los recursos de la Sección A) de la Ley de Minas». Revista de Derecho Urbanístico y Medio Ambiente n. ${ }^{\circ}$ 175. Montecorvo. Madrid.

12 Así lo confirma la sentencia del TSJIB n. ${ }^{\circ}$ 259/2000, de 7 de abril de 2000.
} 
se derogaron por el RD 1131/1988, por lo que las citadas actividades mineras de una parte estarán sometidas a EIA y por otra, sobre su titular va pesar la obligación de elaborar un Plan de Restauración. En este sentido apunta que «de esta manera se produce un doble sometimiento de una misma actividad a dos técnicas preventivas de protección ambiental, lo que resulta innecesario por cuanto que las exigencias y objetivos previstos en el Plan de Restauración pueden quedar garantizados mediante la EIA».

Obviando el análisis de las complejas normas de transición establecidas en el PDS, una disección de su artículo 12 partiría de la sujeción a la obligatoriedad de llevar a cabo el Plan de Restauración según se dispusiera o no de autorización o concesión con anterioridad a su entrada en vigor, sin perjuicio de lo que más adelante matizaremos. Se podría deducir así, que resultarían excluidas de dicha obligación las explotaciones definidas como canteras activas e incorporadas al Plan que se definen en su artículo 3:

«Cantera activa: aquella que dispone de autorización o concesión minera y demás requisitos legales, y no tiene expediente de caducidad con resolución firme.

"Cantera incorporada al Plan: aquella que dispone de autorización o concesión minera, así como de informe favorable de la Comisión Balear de Medio Ambiente o de la Dirección General de Ordenación del Territorio y Urbanismo, según los casos, y se encuentra pendiente de obtener la licencia municipal correspondiente».

Sensu contrario, se encontrarían sujetas aquellas que no dispusieran de título autorizatorio o concesional, actos de intervención administrativa en cuyo proceso de otorgamiento se inserta el Plan de Restauración, de acuerdo con el repetido artículo 12, cuya obtención comportará la inclusión de la cantera en la lista de las incorporadas al PDS, en el catálogo de la Dirección General de Ordenación del Territorio. Resultarían así sujetas a las determinaciones que nos ocupan las siguientes categorías, igualmente definidas en el artículo 3:

"Cantera en tramitación para su adaptación al Plan: aquella que dispone de autorización o concesión minera, está tramitando su adaptación al vigente Plan, y está incluida en el anexo $n^{\circ} 3$.

"Cantera que no ha tramitado su adaptación al Plan: aquella que dispone de autorización o concesión minera y no ha presentado ninguna documentación para su adaptación al vigente Plan, y está incluida en el anexo $n .^{\circ} 4$.

"Cantera inactiva: aquella que conste inscrita de baja en el Libro-Registro de actividades extractivas de la Dirección General de Industria, siempre que no conste justificada su restauración o reutilización». 
Se deberían añadir a la anterior relación las actividades de reexplotación, entendida igualmente en el artículo 3 como «reiniciar la actividad extractiva de una cantera inactiva», y naturalmente, las autorizaciones excepcionales de apertura de nuevas canteras no previstas en los anexos del PDS. En cualquier caso, tal y como hemos avanzado, este hipotético esquema debe ser matizado en la línea de considerar la sujeción a Plan de Restauración a otros supuestos previstos en el RD 2294/1982, al que expresamente se remite la disposición adicional tercera del PDS a los efectos de la aplicación de su artículo 12. Resultará así, que si el planificador territorial pretendía excluir indirectamente algunos supuestos de la necesidad de elaboración de Plan de Restauración no habría conseguido este supuesto objetivo.

Efectivamente, el RD 2294/1982 parte en su artículo 1 de un principio general de sujeción a sus determinaciones ligando el Plan de Restauración a la obtención de autorización de aprovechamiento o concesión de explotación, sin embargo, y a diferencia de lo previsto en el PDS, conforma un régimen que, aún sin tener naturaleza retroactiva prevé, en la aplicación de futuro, supuestos de hecho y realidades existentes con anterioridad. Esta es la situación configurada en su artículo 9, según el cual:

«En los casos en que la autorización de aprovechamiento o la concesión de explotación hayan sido otorgadas con anterioridad a la entrada en vigor del presente Real Decreto, sus titulares, en el plazo máximo de un año, habrán de presentar ante la Dirección Provincial del Ministerio de Industria y Energía o el Órgano competente de la Comunidad Autónoma un estudio de impacto ambiental en el que, partiendo del estado actual de la explotación, se consideren posibles alternativas en orden a la restauración de las áreas que aún no han sido objeto de explotación.

»En el caso de que la Administración estime oportuna la conveniencia de la futura restauración de las áreas aún no explotadas, podrá imponer al titular la obligación de presentar un proyecto de restauración y de llevarlo a cabo en los términos de los arts. 3 y siguientes de este Real Decreto».

En consecuencia, las anteriores prescripciones serán igualmente aplicables a las denominadas por el PDS «cantera activa»y «cantera incorporada al Plan», en los términos fijados en el trascrito artículo de la norma estatal, bien que ceñida la obligación restauradora, como aclara el Tribunal Supremo en su sentencia de 7 de octubre de 1997, en los casos en que la autorización de aprovechamiento o la concesión de explotación hayan sido otorgadas con anterioridad a la entrada en vigor del Real Decreto, a las áreas que aún no hubieran sido explotadas.

Pero a lo anterior se debe añadir la norma especial autonómica ya conocida y referida a las canteras existentes ubicadas en alguna de las áreas de 
especial protección definidas en la LEN, cuyo artículo 22.2, en su inciso final, dispondrá que el Plan de Restauración afectará a todas las canteras abiertas en ellas ubicadas «en toda su extensión». Prescripción que derivando de norma de rango legal dictada en ejercicio de competencia legislativa exclusiva en materia urbanística para determinados espacios singulares de suelo rústico, debe imponerse desde la vertiente de protección territorial sobre la norma sectorial minera de rango reglamentario.

Obtenido el correspondiente título administrativo autorizatorio o concesional, que habrá incorporado el Plan de Restauración, éste se conformará, en palabras del RD 2294/1982 como condición especial de dichos títulos. Se comunicará tal circunstancia por parte del órgano autorizante a la Dirección General de Ordenación del Territorio para que pueda inscribir la cantera en la lista de las incorporadas al Plan dentro del catálogo cuyo mantenimiento se asigna a esta última unidad orgánica; a su vez, el acuerdo de inclusión de la cantera en el catálogo -suponemos que adoptado por la Dirección General de Ordenación del Territorio-, «se comunicará a los ayuntamientos afectados, de acuerdo con lo que establece el artículo 23 de la Ley 8/1987 de Ordenación del Territorio de las Illes Balears, y se publicará en el Boletín Oficial de las Illes Balears». Esta última previsión obligará al estudio de una problemática evidente, relativa a la incidencia de las determinaciones del PDS sobre diversas competencias asignadas al municipio, que pasamos a realizar.

\section{COMPETENCIAS DEL MUNICIPIO E INCIDENCIA DE LAS DETERMINACIONES DEL PDS}

Necesariamente deben ser analizados dos títulos competenciales asignados por la legislación de régimen local a los municipios, de conformidad con las previsiones de la correspondiente normativa sectorial, que se manifiestan en la vinculación establecida al planeamiento municipal y la concurrencia de las autorizaciones sectoriales antes expuestas con los títulos de intervención local en materia de licencias urbanísticas y de actividad.

En la sentencia $n^{\circ}$. 241/2003, de 21 de marzo de 2003, el TSJIB enjuicia el PDS objeto del presente trabajo y en este punto, en unos términos más que didácticos y clarificadores, reafirma la prevalencia de las determinaciones de la ordenación territorial sobre el planeamiento urbanístico:

«La revisión del Plan se dicta en ejercicio de competencias autonómicas en materia de ordenación territorial, estableciendo unos criterios de coordinación territorial de carácter general. Sin duda implica incidir en el ámbito municipal propio del urbanismo. 
"La distinción entre los conceptos "ordenación del territorio" y "urbanismo" es siempre difusa cuando se trata de llevar al análisis de una actuación concreta. Las definiciones genéricas sobre la "ordenación del territorio" lo vinculan con "el conjunto de actuaciones públicas de contenido planificador cuyo objeto consiste en la fijación de los usos del suelo y el equilibrio entre las distintas partes del territorio" (STC 36/1994) por lo que no solo tiene una visión territorial más amplia que el "urbanismo", sino que además incide en aspectos competenciales más globales, sin limitarse al simple examen del uso urbanístico del suelo. La ordenación del territorio conlleva actuaciones coordinadoras de las diversas partes del territorio con un enfoque global, no sólo del uso del suelo, sino del equilibrio socioeconómico del ámbito afectado lo que implica un análisis de la politica de transportes, equipamientos sanitarios, docentes, turísticos, etc... . En suma, la ordenación del territorio comporta una visión global porque necesariamente el ámbito espacial es más amplio y porque afecta a politicas económicas, socioculturales, medioambientales, etc.., de todo este territorio, no limitándose al simple análisis de los usos del suelo.

"Pues bien, toda la dificultad de deslindar los campos propios del urbanismo $y$ de la ordenación territorial, se acrecienta en territorios limitados como el insular en el que los ámbitos horizontales de las distintas competencias se superponen con mayor intensidad en atención a que se concentran sobre superficies espaciales más limitadas

»La ordenación del territorio, que comprende la delimitación de los distintos usos del suelo, no difiere de las materias y funciones que opera el urbanismo, bien que no atiende al ámbito local sino supralocal y sus decisiones atañen a la estructura, disposición y composición de las actividades más determinantes sobre el territorio, vinculando a los planes urbanísticos-artículos 13, 17, 1823 y 28 de la Ley 8/87, ahora artículos 9 y 15 de la Ley de la Comunidad Autónoma 14/2000, y artículo 4 de la Ley de la Comunidad Autónoma 6/99-.

»En consecuencia, para el caso que nos ocupa se aprecia que la regulación se efectúa en base a criterios de coordinación territorial de carácter general, por lo que no se estima violada las competencias urbanísticas municipales, máxime si se atiende a lo ya indicado por la STC 170/1989, de 19 de octubre: "en la relación entre el interés local y el interés supralocal, es claramente predominante este último".»

Algunos ejemplos prácticos de la vinculación que producirán las determinaciones del PDS al planeamiento municipal se encuentran plasmados en otras resoluciones del TSJIB, así en su sentencia $\mathrm{n}^{\circ}$. 259/2000, de 7 de abril de 2000, analizando la prohibición establecida por el plan general del municipio de Eivissa de apertura de canteras dispone, que el Plan Director Sectorial «también vincularía al Plan General de Eivissa y tendría que adaptarse a sus determinaciones -artículo 23.1 de la Ley de la Comunidad Autónoma 8/1987, de 1 de abril, de Ordenación Territorial de las Illes Balears-..»

El PDS configura en definitiva una técnica de vinculación a la planificación municipal totalmente atípica, pues no parte de la previsión concre- 
ta de un ámbito físico definido en el plan supramunicipal (solamente se indican en unos anexos la relación de canteras activas o potencialmente incorporables al Plan), sino que la inclusión de una cantera en el catálogo se lleva a cabo mediante acto administrativo singular, que se comunica al ayuntamiento afectado «de acuerdo con lo que establece el artículo 23 de la Ley 8/1987 de Ordenación del Territorio». Veamos pues que implica el citado artículo de la anterior LOT/1987:

«23.3. Sin perjuicio de la competencia municipal reconocida por las leyes vigentes, los Planes Directores Sectoriales serán vinculantes para los planes urbanísticos regulados por la Ley del Suelo, en aquellos extremos que, por desbordar el interés estrictamente municipal, expresamente señalen. Dichos planes urbanisticos deberán adaptarse a las nuevas determinaciones en los plazos que, a tal efecto, fije el Plan Director Sectorial aprobado. Si la adaptación no se produjera dentro de dichos plazos, la Consellería de Obras Públicas y Ordenación del Territorio podrá subrogarse en las competencias municipales para su redacción y tramitación» ${ }^{13}$.

Veamos a continuación en qué términos se fijan las condiciones y plazos de adaptación del planeamiento urbanístico municipal al PDS, cuestión que pretende regular su artículo 13 bajo el epígrafe de «vinculación al planeamiento municipal»:

"1.- Una vez efectuada la comunicación al ayuntamiento afectado, de acuerdo con el último párrafo del artículo anterior, éste deberá iniciar la tramitación para adaptar la clasificación del suelo a las determinaciones previstas en el presente Plan en un plazo de tres meses, con una calificación, en el ámbito del suelo delimitado en la autorización minera, que sólo admita el uso extractivo y los relacionados con éste, así como los derivados del Plan de Restauración o del proyecto de reutilización.

»2.- Si la adaptación del planeamiento urbanístico no se produce en el plazo de seis meses a partir de la recepción de la comunicación a que hace referencia el apartado anterior, el consell insular correspondiente podrá subrogarse en las competencias municipales para su redacción y tramitación.

\footnotetext{
${ }^{13}$ En términos similares, aunque bajo una cláusula general referida a todos los instrumentos de ordenación en ella contemplada, se refiere el artículo 15 de la vigente LOT/2000, disponiendo:

«1. Los instrumentos de ordenación territorial previstos en esta Ley son vinculantes para los instrumentos de planeamiento urbanístico municipal en todos aquellos aspectos en los que sean predominantes los intereses públicos de carácter supramunicipal.

»2. Los planes afectados por la vinculación establecida en el apartado anterior deben adaptarse en los plazos que fije a este efecto el instrumento de ordenación territorial. Si la adaptación no se produce dentro de estos plazos, el consejo insular correspondiente se podrá subrogar en el ejercicio de las competencias municipales para hacer su redacción y tramitación.

»3. Asimismo, los planes territoriales insulares y los planes directores sectoriales podrán prever el régimen provisional de ordenación que se aplicará en los municipios afectados mientras no se produzca la adaptación de los respectivos planes urbanísticos».
} 
»3.- En caso de concesiones mineras, la adaptación del planeamiento tan sólo afectará al ámbito en que se ubiquen las actividades extractivas.»

Si el planificador pretendía configurar con el anterior precepto una determinación de carácter autoejecutivo, que posibilitara la materialización de forma directa de las actuaciones autorizadas por la Administración minera sin necesidad de adaptación del planeamiento municipal, es evidente que no se ha conseguido el objetivo. Se configura en el plan director un sistema en virtud del cual la materialización de las actuaciones que potencialmente contempla requerirán igualmente la obtención de las autorizaciones municipales, que a la vez deberán atender a las previsiones de su planificación urbanística. Veamos pues las condiciones de vinculación a esa normativa urbanística municipal, establecida en términos peculiares y a la vez confusos. Dicha confusión permitirá la defensa de opciones contrapuestas.

La primera de las opciones defendibles comportaría que la viabilidad de la concesión de las licencias municipales de diverso orden para llevar a cabo la actividad extractiva requeriría la adaptación del plan general municipal o instrumento equivalente, de acuerdo con lo establecido en la correspondiente legislación urbanística. Si el planificador de ordenación territorial quisiera haber configurado un régimen de aplicación directa, debería haber previsto la autoejecutividad de sus determinaciones sin necesidad de adaptación del plan municipal. Fijémonos en un dato significativo: en ningún caso el PDS confiere una clasificación y calificación urbanística de uso extractivo de forma directa, puesto que el ámbito o perímetro de suelo delimitado en la autorización minera no ha sido definido en el propio plan director, sino reconocido mediante una autorización administrativa singular, técnica sobre la cual deberíamos decantarnos por considerar que no puede resultar amparada por la LOT.

Diferente habría sido una redacción de la norma de tipo self executing en unos términos que, a modo de ejemplo, podrían rezar: «sin perjuicio de la posterior adaptación del instrumento de planeamiento urbanístico general al presente Plan, la autorización minera comportará la calificación del ámbito afectado como zona de uso extractivo». En este supuesto, se hubiera permitido la concesión directa de las licencias municipales exigibles. Como dato relevante, con la lectura contrastada del anterior precepto equivalente en el anterior PDS -artículo 15 del Decreto 77/1997, de 11 de junio- se puede observar con claridad el diferente alcance atribuido a la necesidad de adaptación:

«Artículo 15. Relación con el planeamiento urbanístico vigente, vinculaciones que se crean.

»1.- El ámbito del suelo delimitado en la concesión o autorización en la fecha de aprobación inicial del Plan donde se ubiquen las canteras quedará clasifica- 
LA PLANIFICACIÓN TERRITORIAL DE LAS ACTIVIDADES EXTRACTIVAS: COMENTARIO CRÍTICO...

do como no urbanizable, con la calificación de uso extractivo por los instrumentos de planeamiento urbanistico. Con posterioridad a la entrada en vigor de este Plan, todas las actividades o usos diferentes de los amparados en la concesión o autorización se considerarán fuera de ordenación.

»2.- En este suelo no se permitirán otras construcciones que las estrictamente necesarias para el normal desarrollo de la actividad extractiva y establecimientos de beneficio autorizados, que deberán ser autorizados por los ayuntamientos respectivos, de acuerdo con lo que establece el artículo 58 de la Ley del Suelo de 1976.

»3.- Las entidades locales cuyo territorio esté afectado por el Plan deberán adaptar sus determinaciones a su planeamiento general en el plazo de un año, de conformidad con lo establecido en el artículo 9.2 de la Ley del Suelo de 1976.

"4.- La clasificación del suelo como no urbanizable no podrá alterarse hasta que se cumplan totalmente las condiciones establecidas en el Plan de Restauración correspondiente».

Como podemos observar, existe un alcance mucho más directo y próximo a la autoejecutividad en los términos utilizados para la adaptación del planeamiento municipal en la versión del instrumento de ordenación territorial de 1997, que ponen de manifiesto la diferente consideración en la versión revisada en 1999 en cuanto a la remisión a la adaptación del plan urbanístico, para que pueda ser efectiva la concesión de las autorizaciones municipales de diverso orden.

Se debe hacer notar una sutil aunque importante diferencia entre las respectivas redacciones puesto que, si bien la del PDS inicial fijaba igualmente la obligación de adaptación del planeamiento municipal -art. 15.3-, ésta debía simplemente asumir la norma autoejecutiva que derivaba del primer número del mismo artículo, que implicaba que ya se asignase directamente desde el instrumento de ordenación territorial una concreta clasificación y calificación de suelo al instrumento municipal. En cualquier caso, la consideración de determinaciones autoejecutivas tampoco sería posible en atención a lo dispuesto en los artículos 22.c) de la LOT/1987 y 12.c) de la vigente LOT/2000 14 , puesto que no se crea una vinculación directa al planeamiento, sino una previsión aparentemente diferida a su adaptación.

\footnotetext{
${ }^{14}$ Disponía el art. 22.c) de la LOT/1987 que los PDS «se ajustarán a las determinaciones de las Directrices de Ordenación Territorial y constarán de los documentos escritos y gráficos necesarios para reflejar como mínimo los contenidos siguientes:

.../...

c) Articulación con los Planes Territoriales Parciales y con el Planeamiento Municipal existentes, con expresa determinación de las vinculaciones que se creen.» En idéntico sentido, aunque referido a todos los instrumentos regulados en ella, el citado art. 12.c) de la LOT/2000.
} 
Pero ciertamente avanzábamos que el planificador territorial trazaba una peculiar técnica para la posterior adaptación del planeamiento municipal, puesto que la práctica comportará que la adecuación, más que al PDS en sentido estricto lo será a las «autorizaciones sectoriales de incorporación», es decir, a actos administrativos singulares autonómicos que además, estrictamente no serían de desarrollo del plan director, sino claramente finalizadores de procedimientos de autorización minera.

Dicho de otra forma, la adaptación del planeamiento municipal no lo será a una disposición de carácter general de planificación de ordenación territorial, sino a una «comunicación» de un órgano directivo de la Administración autonómica que se limita a recoger e incorporar a un catálogo el acto singular dictado previamente por el competente en materia minera.

Además con esta técnica en la práctica el planificador territorial consigue un resultado totalmente opuesto al perseguido. Difícilmente se producirán o serán factibles adaptaciones por parte del planificador local, puesto que necesariamente serán dinámicas en el tiempo: en función de cada autorización singular se requerirá una nueva y diferente adaptación. Vemos pues que se pervierte la idea de la adaptación reflejada en la LOT, que parte a nuestro entender de la introducción in fine de un único procedimiento mediante el cual, globalmente el municipio adaptará su instrumento de planeamiento urbanístico general a las determinaciones preestablecidas en su término municipal por el plan territorial, sancionándose su incumplimiento con la posibilidad de subrogación competencial en las labores de adaptación. Por el contrario, lo previsto en el PDS implica un número indeterminado de «adaptaciones» que recojan singularmente autorizaciones sectoriales previas.

En definitiva, de compartirse la interpretación expuesta, el planificador de ordenación territorial aboca en la práctica a una situación de inoperatividad de las técnicas de adaptación de la planificación municipal, debiéndose derivar en definitiva a la autorización urbanística de la actividad mediante el mecanismo de la declaración de interés general contemplado en los artículos 26 y 37 de la Ley 6/1997, de 8 de julio, del Suelo Rústi$\mathrm{co}^{15}$ (LSR), técnica más adecuada en atención al componente dinámico de

\footnotetext{
15 «Artículo 26. Actividades declaradas de interés general

1. Las actividades relacionadas con usos no prohibidos, distintos de los admitidos o del de vivienda unifamiliar, solamente podrán autorizarse cuando resulten declaradas de interés general por la comisión insular de urbanismo respectiva, o por el Gobierno de la Comunidad Autónoma de les Illes Balears, en los casos contemplados por el artículo 3.4 de la Ley 9/1990, de 20 de junio, de Atribución de Competencias a los Consells Insulares en Materia de Urbanismo y Habitabilidad.
} 
las sucesivas incorporaciones a los anexos del PDS, que conducirían como se ha visto al absurdo de realizar igual número de modificacionesadaptaciones puntuales del instrumento de ordenación urbanística general para cada una de ellas.

El antecedente inmediato de la declaración de interés general se encuentra en el procedimiento regulado en el Reglamento de Gestión Urbanística para la autorización de instalaciones de utilidad pública o interés social, que remitía inicialmente al procedimiento destinado originariamente a regular la tramitación del planeamiento especial ${ }^{16}$. La clasificación de la parcela como suelo rústico no resultará alterada con el acto de declaración de interés general, pero sí comportará el establecimiento de unos usos a los cuales se dedicará la superficie de terreno y la intensidad en su implantación, derivación de una técnica de zonificación, que en definitiva resultaría manifestación de la actividad de planificación urbanística de los entes públicos. En suma, la técnica de atribución de usos mediante este procedimiento resultará la adecuada para suplir la falta de adecuación obligatoria del planeamiento municipal, que encontrará acogida en el PDS para evitar una hipotética previsión prohibitiva en la implantación del citado uso por parte de un instrumento de planeamiento urbanístico general no adaptado al de ordenación territorial, como hemos podido ver en alguna consideración efectuada por el TSJIB transcrita más arriba.

Además, en estos casos, disponiéndose del amparo de un instrumento de ordenación territorial que a la larga implicaría que las actuaciones a él incorporadas deberían recogerse con carácter imperativo en el plan municipal, la declaración de interés general se convertiría en un trámite de intervención reglado, atributivo de la calificación urbanística de uso extractivo en un suelo rústico.

\footnotetext{
2. La declaración de interés general podrá otorgarse a todas aquellas actividades que, respetando las limitaciones que según los usos establezcan, trasciendan los meros intereses individuales, sean compatibles con el grado de protección de la zona y, en el caso de que supongan la construcción de nuevas edificaciones, resulten de necesaria ubicación en el suelo rústico».

${ }^{16}$ De hecho, la tramitación procedimental establecida en el artículo 37 de la LSR participa de un componente de participación pública semejante a la que se asigna a instrumentos de planeamiento de desarrollo parcial o especial, al iniciarse a solicitud del interesado en llevar a cabo la actividad ante el ayuntamiento, que la remitirá al órgano que deba declararla junto con un informe municipal razonado sobre la misma. El órgano que deba efectuar la declaración someterá el expediente al trámite de información pública durante el plazo de quince días, mediante anuncio que se publicará en el «Butlletí Oficial de la Comunitat Autònoma de les Illes Balears» y en el tablón de anuncios del ayuntamiento correspondiente, y a informe, durante idéntico plazo, de los organismos y administraciones con competencias en la materia de que se trate. Efectuados los trámites señalados el órgano competente resolverá, de forma motivada y la notificará al ayuntamiento y al interesado.
} 
El amparo de la actividad en el PDS y su carácter vinculante para el plan municipal, a la vez, y en el procedimiento alternativo de declaración de interés general, permitiría eludir el procedimiento excepcional previsto en el artículo 37.5 de la LSR, que dispone:

"Cuando la actividad se vincule a un uso prohibido por el instrumento de planeamiento general, y el órgano competente para la declaración de interés general, previo dictamen del Consell Consultiu de les Illes Balears, estimase la necesidad de su implantación, propondrá al plenario del consell insular respectivo la suspensión del planeamiento, para su revisión o modificación, en los términos previstos en la legislación urbanística».

Dicha elusión en definitiva no supondría infracción legal, puesto que por idéntica determinación legal igualmente el plan municipal debe incorporar finalmente el uso extractivo como admisible en el ámbito de la autorización sectorial minera; la declaración de interés general así, únicamente anticiparía formalmente el resultado preestablecido de incorporación de la actividad en el plan municipal. Por ello, no es necesario en el trámite de interés general seguir el procedimiento excepcional previsto en el citado artículo 37.5 de la LRS, más si se tiene en cuenta que la figura de los planes directores sectoriales no requieren la intervención de la Administración consultiva en su procedimiento de elaboración y aprobación. Así lo confirman, entre otras, las sentencias del TSJIB $n^{\circ}$. 280/2001, de 9 de marzo de $2001 \mathrm{y} \mathrm{n}^{\circ} .27 / 2002$, de 8 de enero de 2002.

Apuntábamos en cualquier caso una opción alternativa de diferente contenido que podría partir, más que de una lectura literal de los términos del artículo 13 del vigente PDS, de una interpretación finalista en orden a facilitar la regulación urbanística de una actividad de explotación de recursos desde una visión de todo el territorio insular. En la misma línea, se debería acudir a una interpretación basada en una continuación de los objetivos explícitos de la versión del PDS anterior a su revisión -artículo 15 del Decreto 77/1997, de 11 de junio, trascrito más arriba-; dicho de otra manera: considerar que la «adaptación» del instrumento de planejamiento urbanístico con una calificación «uso extractivo y los relacionados con éste, así como los derivados del Plan de Restauración o del proyecto de reutilización» -artículo 13 del vigente plan- ha de ser necesariamente a una determinación implícita del PDS, que habría ya asumido tal clasificación de suelo rústico como establecía la versión anterior.

Argumentos que se podrían asimismo reforzar con relación a las denominadas «canteras activas» en la definición que efectúa el PDS: aún no contempladas en el instrumento de planeamiento urbanístico se encontrarían en situación de legalidad. En lo referente a las «canteras incorpora- 
das», en una línea similar y al establecerse la adaptación del plan municipal como un acto debido, podría sostenerse que su no realización no seria obstáculo impeditivo para la concesión de las autorizaciones municipales de obra y de apertura ${ }^{17}$.

Se añadiría a todo lo anterior alguna resolución judicial, como la ya aludida sentencia $\mathrm{n}^{\circ}$. 259/2000, de 7 de abril, en la que el TSJIB aún encontrándose con una prohibición de uso como cantera establecida en un plan general de ordenación, insinuaría una vinculación directa del PDS, debiendo aquel adaptarse a sus determinaciones. Dicho de otra manera, quizás entendiendo la existencia de una vinculación autoejecutiva y no diferida a la adaptación al instrumento de ordenación territorial.

Del mismo modo, aunque sin entrar a valorar como ratio decidendi la incidencia de la previa adaptación, la sentencia 144/2003 del Juzgado Contencioso Administrativo $\mathrm{n}^{\circ} .2$ de Palma, de 17 de junio de 2003, confirmada en apelación por el TSJIB en su sentencia $\mathrm{n}^{\circ}$. 50/2005, de 25 de enero de 2005; en la que pareciera aludir a que la habilitación directa para el desarrollo de la actividad minera nace directamente de las determinaciones del PDS, pero dependiendo del tipo de anexo y catálogo en donde estuviese incluida la concreta cantera, para considerar la posibilidad de concesión de la pertinente licencia municipal de funcionamiento.

Se ha podido deducir de lo dicho hasta ahora, que a pesar de la vinculación del PDS sobre el instrumento de planeamiento municipal, resulta inalterado el ejercicio de las competencias locales relativas a las licencias urbanísticas y de funcionamiento de las correspondientes actividades. Tampoco se neutralizaría de forma absoluta la concurrencia de otras autorizaciones urbanísticas, en concreto la relativa a la declaración urbanística de interés general del correspondiente proyecto, aunque de alguna manera se pudiera modalizar. El TSJIB en alguna sentencia como la $n^{0}$. 658/1998, de 29 de octubre de 1998, y aunque referida al análisis de una resolución municipal dictada con anterioridad a la existencia del primer PDS de Canteras, disponía la necesidad de obtener la citada autorización concurrente:

«La necesidad de la obtención de la declaración de interés social de la cantera, como requisito previo a la concesión de la licencia de su apertura, es incuestionable desde el momento en que se encuentra en una zona declarada como "no

\footnotetext{
17 Véase, en este sentido, los estrictos términos de sus definiciones, que las conceptúan como aquellas que dispongan de autorización o concesión minera y resto de requisitos legales; o pendiente de obtener la licencia municipal correspondiente, respectivamente; considerándose además que en ningún caso añade el redactor del PDS unos términos del orden «... por falta de adaptación de planeamiento».
} 
urbanizable”. Por lo que es de plena aplicación el art. $16.2^{\circ}-3^{a}$ de la Ley del Suelo de 1.992 que exige dicha declaración de utilidad pública o interés social en edificaciones o instalaciones que hayan de emplazarse en el medio rural. El argumento de la parte demandante en el sentido de que ello sólo afecta a "construcciones e instalaciones" y no a la "actividad extractiva en si misma considerada", debe rechazarse ya que la descripción del precepto no es limitativa y en todo caso la sujeción de la "actividad" a licencia (y consiguiente previa declaración de interés social) ya viene descrita en el art. 2,5 de la Ley 10/90 de Disciplina Urbanistica de esta Comunidad. Más claro es el decreto del Govern Balear 75/1989 de 6 de julio ya que al regular el objeto de las declaraciones de utilidad pública o interés social, no las limita a las "obras e instalaciones" sino que expresamente incluye "las actividades y usos", dentro de los que, incuestionablemente, cabe contemplar la actividad extractiva de minerales. Asi pues, no podia concederse licencia sin que previamente se instase dicha declaración. Por ello, el Decreto impugnado se ajusta a Derecho».

Traemos a colación la anterior resolución judicial para intentar aclarar el equívoco consistente en entender que la previsión del establecimiento de una cantera en el PDS o su incorporación al plan municipal en el proceso de adaptación evitaría la necesidad de declaración de interés general urbanística (con la salvedad de las conceptuadas como «canteras activas» en los términos anteriormente expuestos, y en alguna medida pudiera sostenerse que también las «canteras incorporadas»). A nuestro entender no es asumible la anterior interpretación por una serie de razones.

En primer lugar, se debe apuntar que resulta meridianamente claro, como podremos ver seguidamente, que las previsiones del PDS no eliminan en ningún caso la necesidad de obtención de las correspondientes licencias municipales urbanística y de actividad. Si ello es así, la lógica impone que tampoco neutralizará el PDS la necesidad de intervención de la Administración insular urbanística mediante la declaración de interés general para la implantación de dicha actividad ex novo en el suelo rústico.

Reafirmará esta postura lo dispuesto en la LSR, ya que para la implantación de actividades en esta categoría de suelo, únicamente permite prescindir del trámite con relación a las previstas en su artículo 21 referidas a la explotación agrícola o forestal de las fincas ${ }^{18}$, y con relación a las

18 «Artículo 21. Actividades relacionadas con el destino o con la naturaleza de las fincas

1. Tendrán la consideración de actividades relacionadas con el destino o con la naturaleza de las fincas las vinculadas a los siguientes usos:

a) los afectos a la explotación de agrícola, forestal, pecuaria y cinegética, así como a la conservación y a la defensa del medio natural;

b) los recreativos, educativos, culturales y científicos efectuados en el marco de lo dispuesto por la Ley 4/1989, de 27 de marzo, de Conservación de los Espacios Naturales y de la Flora y Fauna Sil- 
infraestructuras públicas previstas en su artículo 24 aunque para ser consideradas como un uso admitido, y en consecuencia prescindir del trámite de declaración de interés general, se exigirá por el citado precepto su previsión «en los instrumentos de planeamiento general o en los instrumentos de ordenación territorial», exoneración que no es aplicable con relación a las actividades extractivas, que se distinguen y diferencian expresamente de las infraestructuras públicas en la matriz de ordenación del suelo rústico de la LDOT, norma legal de aplicación directa.

La actividad extractiva, por tanto, en la definición que de ella efectúa la LDOT, no puede entenderse como actividad exenta de la declaración de interés general, con independencia de que su previsión en el PDS vincule al plan municipal en los términos más arriba expuestos. La vinculación, en aplicación del artículo 23 de la LOT/1987 y 15 de la LOT/2000, supondrá la necesidad de calificación de una parcela con previsión de un uso urbanístico extractivo, que posibilitará la tramitación administrativa de las autorizaciones urbanísticas, pero en ningún caso la citada vinculación tiene alcance para variar la consideración de uso condicionado de la actividad extractiva, y por tanto sujeta a previa declaración de interés general ${ }^{19}$. Cuestión distinta será, como ya hemos expuesto, que como consecuencia de tal previsión en el PDS, la declaración de interés general devenga en cierta manera reglada una vez obtenidas las autorizaciones contempladas en el instrumento de ordenación territorial.

En cualquier caso, y aún de no compartirse lo anterior, el control urbanístico asignado a la licencia municipal de obra y de actividad tampoco se ve neutralizado por las previsiones del PDS o la legislación sectorial minera. Resultan aquí interesantes las consideraciones que extrae QuINTANA LÓPEZ ${ }^{20}$, respecto de la reinterpretación que ha realizado la jurisprudencia del artículo 116.1 de la Ley de Minas, que prohibía que ninguna autoridad administrativa diferente de la competente en la rama de la minería pudiese suspender trabajos de aprovechamiento de recursos minerales que estuviesen autorizados de acuerdo con las disposiciones de la legislación sectorial minera, precepto que podría haber impedido en su literali-

\footnotetext{
vestres, o al amparo de lo dispuesto por la Ley 8/1987, de 1 de abril, de Ordenación Territorial de las Islas Baleares.

19 Véanse en este sentido nuestras consideraciones en cuanto a la distinción conceptual entre «uso condicionado» y «condiciones de autorización» que efectuamos en «L'activitat urbanística en el sòl rústic. Comentari al Títol III de la Llei 6/1997, de 8 de juliol». (2004) Edicions U.I.B. Palma.

20 Tomás QuinTANa LóPEZ, 1997, «Tradición y renovación en el control urbanístico de los usos constructivos en suelo no urbanizable». Revista de Derecho Urbanístico, $n^{\circ}$. 158. Diciembre. Editorial Montecorvo. Madrid.
} 
dad que las Administraciones urbanísticas diferentes a la minera pudiesen ejercer con eficacia sus competencias.

Así, el TS mantiene la concurrencia de títulos a otorgar por la Administración sectorial minera con las licencias y autorizaciones que otras Administraciones diferentes hayan de expedir igualmente para legitimar el ejercicio de las actividades extractivas. En este sentido en su sentencia de 1 de febrero de 1988, establecerá que el sometimiento a licencia municipal de la actividad de extracción de roca de una cantera, se desprenderá claramente de la normativa sectorial correspondiente, «por tratarse de un supuesto de competencias concurrentes en el que la autoridad municipal, por una parte, y la Administración del ramo de Minas por otra, actúan en régimen de independencia procedimental y cada una con facultades intervencionistas propias».

En consecuencia, ninguna duda existe en el hecho de que la existencia del PDS de Canteras no neutraliza la necesaria sujeción de las actividades extractivas a las pertinentes licencias municipales urbanísticas y de actividad, circunstancia que se ve reforzada por la contundente doctrina jurisprudencial elaborada por el TSJIB, partiendo de su sentencia $\mathrm{n}^{\circ}$. 657/1998, de 29 d'octubre de 1998, que se remite a su vez a la del TS de fecha 22 de mayo de 1993:

«... cuando se trata, en concreto, de la simple explotación de una cantera, por la Ley de Minas de 21 de julio de 1973, se requiere la autorización por parte del órgano exclusivamente competente según ésta para concederla, ya sea de carácter estatal o autonómico; pero, al mismo tiempo, se ha de obtener una licencia que, por el contrario, compete conceder a la Administración Municipal, que, por su parte, impone para todos los casos el Texto Refundido de la Ley sobre Régimen del Suelo, en relación con el Reglamento de Servicios de 17 de junio de 1955, y, en los semejantes al que nos ocupa, además, el de Actividades Molestas, Insalubres, Nocivas y Peligrosas de 30 de noviembre de 1961.......

„Cuarto.- Por tal diferenciación y porque, como también se dejó explicado, de ella deriva la distinta normativa legal a la que, en el ejercicio de sus respectivas competencias, han de atenerse las Administraciones estatal, autonómica y local en función de las materias sobre las que las privativas facultades se ejercitan, al tiempo de examinar el alcance que pudiera tener la Resolución del Parlamento de las Islas Baleares para hacer inviable el Acuerdo municipal de cierre y clausura de la cantera en explotación, hay que ilustrar, en aras de una clarificación del problema, que no puede entenderse que la medida cautelar que por la misma se adoptaba, aun cuando se correspondiera con un Plan urbanístico de carácter más amplio, no podía interferir en la competencia municipal para paralizar una actividad que se desarrollaba sin licencia, ya que aquella prohibición de suspender la explotación de las canteras en funcionamiento y de no conceder autorización para la explotación en lo sucesivo era de exclusiva aplicación hasta tanto se elaboraba el Plan Sectorial de Canteras previsto en aquél; y de ahi también que no se pueda detectar la incompetencia municipal para acordar aquella suspensión porque hubiera infringido el artículo 116 de la repetida Ley de Minas, ya que 
por ese mismo carácter especial de tal legislación, la prohibición en cuestión sólo se proyecta respecto de Órganos o Autoridades administrativas estatales o, en su caso, autonómicas, en tanto, el Acuerdo recurrido lo que trataba de impedir era el ejercicio de una actividad que, cualquiera que fuera su objeto a tenor de una normativa especifica, por su acusado carácter molesto y peligroso, no podía funcionar sin la correspondiente licencia de apertura.

»Así pues, la licencia municipal de apertura y posterior inspección prevista en el art. 34 del Reglamento de Actividades Molestas..., es necesaria en todo caso y con independencia de que la actividad cuente con la también preceptiva autorización de la Dirección General de Minas.

»A mayor abundamiento, la exigencia de licencia no sólo viene impuesta por el indicado Reglamento, sino por la propia Ley 10/90 de Disciplina Urbanística que en su art. $1^{\circ}$ y a la exige para cualquier aprovechamiento o uso del suelo, incluyendo expresamente las "actividades extractivas de minerales" en su art. 2,5 .

"Pues bien, a pesar de posibles autorizaciones de extracción anteriores a 1.990, en todo caso se carecía de la oportuna licencia y tales extracciones se reiniciaron en fechas inmediatamente anteriores a la denuncia de 1.992, por lo que si en estas fechas se iniciaba la actividad extractiva de nuevo, dicha actividad se debía acomodar a la legislación vigente (ley 10/90) que, en realidad, no introduce una novedad respecto a la exigencia de licencia municipal previa».

En la misma línea, la sentencia del mismo Tribunal no ${ }^{\circ}$ 259/2000, de 7 de abril de 2000, aclarando expresamente que el ejercicio de cualquier actividad clasificada requiere la obtención de licencia municipal de instalación y licencia municipal de apertura y funcionamiento, «debiendo obtenerse previamente a ésta ultima las autorizaciones precisas en cada caso -artículo 16 de la Ley 8/95-».

Debemos destacar el último inciso de la anterior sentencia para aclarar que en ningún caso hubiera podido ser aplicable, en el punto que ahora nos ocupa, la previsión excepcional contemplada en la disposición adicional sexta de la Ley balear 8/1995, de 30 de marzo, de Actividades Clasificadas, según la cual la ejecución de actividades programadas en un Plan Territorial o Plan Director sectorial, que incluya su calificación, instalación, apertura y funcionamiento, no estará sujeta a las licencias, autorizaciones e informes que dicha norma legal contempla en materia de actividades. De un lado, la previsión excepcional, pensada en un principio para actuaciones públicas, no podría ser aplicable al no incluir el PDS los requisitos individualizados exigidos para cada cantera.

No obstante, la aplicación práctica de la expresada disposición adicional por parte del orden contencioso administrativo no ha estado exenta de problemática. Así, la expresada sentencia 144/2003 del Juzgado Contencioso Administrativo ${ }^{\circ} .2$ de Palma, de 17 de junio de 2003, alude al hecho de que las potestades de policía municipales para ordenar la parali- 
zación de la actividad minera sobre la base de las determinaciones de la Ley 8/1995, radicarían en su consideración de actividad clasificada, pero añadiendo «aunque la concesión de licencia se sustituya por la inclusión en el Plan Director Sectorial de Canteras».

Tesis, la anterior, que confrontaría con la argumentación que hemos ofrecido en cuanto a que de la citada disposición adicional sexta de la Ley 8/1995 sólo pudieran beneficiarse las actuaciones públicas y que, por otro lado, entraría en evidente contradicción con las consideraciones de una anterior sentencia del TSJIB, la $\mathrm{n}^{\circ}$. 503/2003, de 6 de junio de 2003, según la cual «...el Plan no interfiere en las competencias urbanísticas municipales ni en las Leyes (como la 10/90 de Disciplina Urbanística) que exigen licencia municipal para las actividades extractivas. Son cuestiones distintas la legalización contemplada en el Decreto 61/1999 en el ejercicio de competencias mineras, de medio ambiente y de ordenación territorial, de la legalidad urbanística y correlativa competencia municipal sobre la misma. En definitiva, el Plan no prevé que la adaptación al mismo haya de suponer la innecesariedad de la licencia municipal o la posibilidad de que se ejercite la actividad extractiva sin necesidad de licencia municipal».

Más aún, ante el planteamiento de conflicto en defensa de la autonomía local contra el artículo 17 de la Ley autonómica 12/1999, de medidas tributarias, administrativas y de función pública y económicas, que añadió a la Ley 8/1995 la conflictiva disposición adicional sexta, el Consell Consultiu de les Illes Balears dictaminó la viabilidad del conflicto, que fue admitido a trámite por parte del Tribunal Constitucional. Esta situación provocó que por una nueva norma autonómica ad hoc, la Ley 9/2000, de 27 de octubre, se modificase el contenido del régimen especial de la disposición adicional quedando con la siguiente redacción:

«Disposición adicional sexta. Actividades previstas en los instrumentos de ordenación del territorio.

»1. La ejecución de actividades de interés supramunicipal previstas en un plan territorial parcial o en un plan director sectorial, en materia de residuos, que exija su calificación, instalación, apertura o funcionamiento, no estará sujeta al régimen de licencias, autorizaciones e informes establecido en esta ley.

"2. Lo dispuesto en el número anterior sólo será aplicable a los proyectos previstos expresamente en los instrumentos de ordenación citados, siempre que estén recogidos con el grado de detalle suficiente para evaluar sus características fundamentales».

El legislador, saliendo al paso de los reparos considerados por el Consejo Consultivo con relación a la anterior redacción, justificó la nueva propuesta en la exposición de motivos de la Ley modificativa con base a 
«la necesidad de esclarecer el alcance de la citada disposición adicional, así como de fijar con precisión los límites a la autonomía reconocida constitucionalmente a los municipios», factores que aconsejaban «modificar la redacción aprobada en su momento».

Ante el planteamiento de un nuevo conflicto de constitucionalidad en defensa de la autonomía local contra la reforma legislativa, la Administración consultiva dictaminó en este caso su plena adecuación al marco legislativo, a la vista de los nuevos márgenes concretados en favor de unas actividades singulares de gestión de residuos y no a través de una previsión de exoneración generalizada, como contemplaba la redacción anterior. (Dictamen del Consell Consultiu de les Illes Balears $n^{\circ}$. 44/2001, de 24 de mayo).

\section{INSPECCIÓN Y CONTROL DE LOS PLANES DE RESTAURACIÓN Y FIANZAS DE RESTAURACIÓN}

Estos tres aspectos se encuentran regulados en los capítulos quinto y sexto de la normativa del PDS, y sin duda constituyen una manifestación explícita de normativa complementaria de la regulación administrativa de la materia llevada a cabo por el RD 2994/1982, confirmando el carácter más que parcial de norma reglamentaria dictada en ejecución y desarrollo de las competencias autonómicas en materia medioambiental y minera, que no estrictamente de ordenación territorial. Por poner un primer ejemplo, el artículo 14 supondrá una norma reglamentaria de autoorganización en aplicación de las competencias en materia de minería:

"Corresponde a la Dirección General de Industria la inspección y control de los planes de restauración, de acuerdo con lo dispuesto en la normativa minera.

„El responsable técnico, a que se refiere el artículo 12, encargado de la ejecución del plan de Restauración, deberá informar anualmente, en su caso, sobre el cumplimiento de éste dentro del Plan de Labores, a la Dirección General de Industria. De este informe se remitirá copia a la Comisión Balear de Medio Ambiente, a efectos de su conocimiento y a fin de que, si lo considera oportuno, pueda emitir el informe correspondiente sobre el cumplimiento del mencionado Plan de Restauración».

Se concreta en definitiva un aspecto de organización de las actividades inspectoras que se definen en el RD 2994/1982, con amparo evidente en las funciones traspasadas a nuestra comunidad autónoma mediante el Real Decreto 2169/1993, de 10 de diciembre, en materia de minas. Se realiza por tanto un desarrollo normativo de régimen orgánico y también material, como es el establecimiento de la figura de encargado técnico del Plan 
de Restauración y se le asignan una serie de obligaciones no reguladas expresamente en la normativa estatal ${ }^{21}$. Por esta misma razón, la previsión de un régimen sancionador en el artículo 15 del $\mathrm{PDS}^{22}$ se remite, como no podía ser de otra manera sin incurrir en ilegalidad manifiesta, a la aplicación de las sanciones administrativas previstas en la legislación de minas ante el posible incumplimiento del plan de restauración, legislación a la que a su vez se remite el artículo 7 del RD 2994/1982. Interconexión también evidente en lo relativo a la concreción del régimen de las fianzas ${ }^{23}$

21 Cabría preguntarse si la figura de encargado técnico del Plan de Restauración pueda considerarse una figura distinta del director facultativo de la actividad extractiva, previsto en el RD 863/1985, de 2 de abril, por el que se aprueba el Reglamento General de Normas Básicas de Seguridad Minera. A la anterior figura se alude por parte del TSJIB en su sentencia n. ${ }^{\circ} 376 / 02$, de 23 de abril de 2002, en que confirma la legalidad de una resolución del Director General de Industria que denegaba el nombramiento como director facultativo de explotación minera, por infracción del citado Real Decreto y la Orden de 22 de marzo de 1988, al establecer que el número máximo de canteras que podía estar a cargo de un mismo director facultativo era de diez.

22 «Artículo 15. Régimen sancionador.

1. El incumplimiento del Plan de Restauración conllevará la aplicación de las sanciones administrativas previstas en la legislación de minas, independientemente de las que sean exigibles en vía penal, civil o de otro orden por los perjuicios causados al medio ambiente.

2. Sin perjuicio de lo anterior, cuando el titular incumpla totalmente o parcialmente el Plan de Restauración, la administración competente podrá acordar la suspensión provisional de los trabajos de aprovechamiento, de conformidad con los trámites previstos en la normativa minera».

23 «Artículo 16. Objeto, importe y constitución.

1. La fianza tiene por objeto garantizar la ejecución de los trabajos de restauración de las canteras.

2. Su importe será equivalente al coste de los trabajos de restauración proyectados en el Plan de Restauración aprobado. Se establece el baremo siguiente, que deberá actualizarse anualmente de acuerdo con el Índice de Precios al Consumo en las Illes Balears:

a. Para la restauración mediante relleno de canteras excavadas en profundidad, en ningún caso podrá ser inferior a 400.000 ptas. por hectárea de superficie afectada;

b. Para la restauración mediante abancalamiento, en ningún caso podrá ser inferior a 800.000 ptas. por hectárea de superficie afectada.

3. La fianza podrá constituirse mediante cualquier medio admitido en derecho. En caso de constituirse en metálico deberá depositarse en la Caja General de Depósitos del Govern Balear, y en caso de constituirse mediante títulos valor, en la Tesorería General de la CAIB.

4. Si la explotación se desarrolla en distintas fases, la fianza se podrá satisfacer de forma gradual, de manera que los importes depositados correspondan respectivamente al coste de restauración originado en cada fase de la explotación.

Artículo 17. Actualización.

El titular de la explotación vendrá obligado a actualizar la fianza cada tres años durante la vigencia de la concesión o autorización de la explotación, de acuerdo con la variación anual del Índice de Precios al Consumo en las Baleares, en un periodo no superior a treinta días a contar desde la fecha de su publicación. 
(artículos 16 a 18), como reconocen expresamente las disposiciones adicionales tercera y cuarta del PDS al remitirse a la norma estatal.

Reiteramos que estos dos capítulos del PDS son manifestación de títulos competenciales distintos a los de ordenación territorial, y suponen desarrollo reglamentario del RD 2994/1982, que autorizaba efectivamente al Ministerio de Industria y Energía para llevarlo a término, autorización que debe entenderse referida a los órganos competentes de nuestra comunidad autónoma tras el proceso de transferencia, supuestamente en favor de órganos titulares de la potestad reglamentaria de desarrollo normativo en materia minera, pero no para que fuera llevada a cabo dicha función mediante procesos de aprobación de instrumentos de ordenación territorial.

\section{LA POSIBLE REUTILIZACIÓN DE LAS CANTERAS PARA USOS NO EXTRACTIVOS}

Prevé finalmente el PDS una disposición un tanto atípica relativa a la hipotética utilización de las instalaciones inactivas en cuanto a la actividad de extracción de material para su destino a otros usos. En este sentido, el artículo 19 contempla una regla inicial en virtud de la cual la Dirección General de Industria podrá autorizar, a solicitud de la persona interesada y previa autorización del titular del terreno, que el espacio ocupado por una cantera inactiva sea aprovechado para otras actividades distintas de las extractivas. En la solicitud de autorización minera se deberá acompañar un Proyecto de reutilización, que contendrá una evaluación de

Artículo 18. Devolución y plazo de garantía.

1. La devolución de la fianza se formalizará por la Dirección General de Industria al acabar el periodo de garantía indicado en la autorización, previo informe de la CBMA (Comisión Balear de Medio Ambiente) y a petición del titular, siempre que los trabajos de restauración hayan cumplido los objetivos previstos en el Plan de Restauración.

2. Así mismo, cuando los titulares hayan ejecutado parcialmente los planes de restauración, podrán solicitar la reducción de los depósitos en la parte que corresponda a las etapas o fases ya realizadas.

3. El plazo de garantía no será inferior a dos años ni superior a cinco, a contar desde la finalización de los trabajos de restauración, y se fijará en función del tipo de restauración que se efectúe.

4. Previa autorización de la Dirección General de Industria, un tercero podrá subrogarse en las obligaciones del titular de la explotación para el mantenimiento de la restauración efectuada, siempre que, durante el periodo de garantía pendiente deposite la fianza equivalente. En este caso, se establece la posibilidad de devolver la fianza original a su depositario.

5. Cuando el titular del terreno sea persona distinta al explotador, aquel vendrá obligado a autorizar las actuaciones necesarias derivadas del cumplimiento del Plan de Restauración». 
impacto ambiental así como las medidas de seguridad necesarias exigidas por la normativa aplicable.

Como decimos dicha previsión es un tanto atípica, desde el momento en que la Administración minera, atendiendo a los términos literales de la previsión del PDS, debe autorizar en el ámbito de una cantera inactiva su posible utilización para otras actividades ajenas a su título de intervención.

En consecuencia la autorización prevista en el plan sectorial debe ser matizada, puesto que en aplicación del principio de ejercicio de la competencia propia asignada por el ordenamiento jurídico, su autorización no debe entenderse comprensiva de la «realización de actividades diferentes de las extractivas»; por tanto, dicha autorización no suplirá en ningún caso las autorizaciones concurrentes derivadas de otros órdenes como el urbanístico o el de policía de actividades, que se mantendrán obviamente en la esfera de actuación de las Administraciones que ostenten su titularidad. Afortunadamente se encarga de recordar este punto de forma expresa la citada disposición al aclarar que esa posibilidad «se establece sin perjuicio de las correspondientes licencias, permisos o autorizaciones que corresponda otorgar al ayuntamiento u organismos competentes».

Pero incluso para el caso de canteras activas, se prevé idéntica posibilidad, al disponer que en esta situación, la Dirección General de Industria podrá autorizar la sustitución del Plan de Restauración por un Proyecto de reutilización presentado por el titular de los derechos mineros, con el mismo contenido al expuesto en el caso de las canteras inactivas.

Se debe entender así como una autorización sectorial minera diferente de la extractiva, en que se analizará estrictamente la interacción de la actividad propuesta con la regulación de aquel orden, que analizará el proyecto de reutilización. Entendemos que una vez más se está introduciendo regulación estricta desde la perspectiva del régimen minero, y complemento de normativa de regulación medioambiental desde el momento en que se crea un nuevo supuesto de exigencia de EIA, no contemplado en la norma reguladora autonómica, el ya conocido Decreto 4/1986.

Confirma esta última consideración un hecho significativo, como es el que en los casos de reutilización de canteras no se produce el efecto vinculante para el planeamiento municipal urbanístico, desde el momento en que estas posibilidades no se ligan a la necesidad de adaptación de los citados instrumentos (véase que el artículo 13 no incluye los supuestos del artículo 19, sino solo las canteras que se incorporen al plan para su explo- 
tación extractiva). Supondrá por tanto que la obtención de una «autorización de reutilización» minera, a diferencia del régimen general establecido en el PDS, no comportará que las autorizaciones de orden urbanístico que atribuyan el uso propuesto deban ser consideradas regladas en ningún caso. Será el municipio correspondiente quién deberá regular, voluntariamente, en su planeamiento municipal la posibilidad de reflejar este tipo de actividades como admitidas o condicionadas a la declaración urbanística de interés general, según exija la LSR y demás normativa aplicable.

Pero la regulación de usos diferentes a los extractivos se complementará, en el ámbito territorial de la isla de Mallorca, aún con otras determinaciones previstas en otro plan de ordenación territorial. Nos referimos concretamente al Plan Director Sectorial para la gestión de los residuos de construcción, demolición, voluminosos y neumáticos fuera de uso de la isla de Mallorca (PDSRC), aprobado definitivamente por parte del correspondiente Consell Insular ${ }^{24}$.

El citado PDSRC posibilita la conversión de canteras activas e inactivas en posibles vertederos, aunque evidentemente entendidos en el contexto de aquel instrumento de planificación como instalaciones de «eliminación que se destina al depósito controlado del rechazo no valorizable que se origina en las plantas de tratamiento o de separación de los residuos de la construcción y la demolición,...», ligándose este uso alternativo al concepto de restauración, entendido a la vez como la devolución «al espacio alterado por las actividades extractivas de sus características originales o proceder a su integración desde el punto de vista medioambiental y paisajístico», añadiéndose que, en todo caso, la restauración de una cantera se considerará valorización del residuo de construcción o demolición inerte que se destine a este fin.

En este orden de cosas, el PDSRC partirá de la priorización en el uso de los subproductos procedentes del tratamiento de los residuos de construcción o demolición, estableciendo una jerarquía en su utilización que asignará prioridad a la fabricación de nuevos productos (valorización material), o como primera materia secundaria para utilización en obra civil, contemplando finalmente que los subproductos no aptos para los anteriores usos se destinen a la restauración de canteras según lo previsto en la normativa vigente.

Será el artículo 21 del citado plan el que establezca unas medidas para el momento de los subproductos en la restauración de canteras activas e inactivas:

\footnotetext{
24 Acuerdo del Pleno del Consell Insular de Mallorca de 8 de abril de 2002, de aprobación definitiva, publicado en el BOIB, n. ${ }^{\circ}$ 59, de 16 de mayo de 2002.
} 
«Mediante la creación del Consorcio para la Restauración o la Reutilización de las Canteras Inactivas previsto en el Plan director sectorial de canteras se fomenta el uso de subproductos procedentes del tratamiento de residuos de construcción-demolición en la restauración de canteras inactivas. Esta restauración de las canteras inactivas lleva implícita la declaración de utilidad pública a efectos de expropiación forzosa y no es preciso solicitar la condición de interés general.

„Cualquier cantera activa obligada a ser restaurada mediante relleno y que incumpla los plazos previstos en su plan de restauración está obligada a aceptar los residuos de construcción-demolición previamente tratados y procedentes de las plantas de tratamiento del servicio público insularizado sin ningún coste adicional para dicho servicio público.

"Los propietarios de canteras podrán firmar acuerdos voluntarios con el Consell de Mallorca a los efectos de su restauración».

Nuevamente es necesario realizar una precisión a las anteriores previsiones. En coherencia con lo que hemos defendido más arriba, la alusión a una confusa «condición de interés general» de la actividad de «restauración», aún contemplada en el PDSRC, si pretende asimilarse a la declaración de interés general prevista en la LSR resulta una previsión sin amparo legal. Tal y como ya hemos argumentado, la asignación a un ámbito territorial del suelo rústico de un uso diferente de las actividades vinculadas con la naturaleza de las fincas o de las infraestructuras públicas contempladas en un instrumento de planificación, por determinación legal en ningún caso puede reputarse excluida de la preceptiva declaración urbanística de interés general.

El evidente exceso de la anterior previsión del planificador sectorial se pondrá de manifiesto, sensu contrario, en el mismo PDSRC cuando más adelante permitirá - art. 25-, de forma correcta, prescindir del trámite de declaración de interés general estrictamente con referencia a las obras de infraestructura previstas en aquel instrumento. En este caso se referirá específicamente a la ubicación en el territorio de las infraestructuras entendidas en sentido estricto, que deben concretarse en las previstas en su anexo VI: centros de transferencia y pretratamiento, planta de tratamiento y depósitos de rechazo ${ }^{25}$.

${ }^{23}$ Dispone el citado precepto del PDSRC: «Artículo 25. Declaración de utilidad pública, de interés general y licencia de obras y explotación.

»Todas las obras, las instalaciones y los servicios, incluidos accesos, previstos de forma concreta por este Plan director sectorial llevan implícita la declaración de utilidad pública a efectos de expropiación forzosa de los terrenos necesarios para materializarlos.

»Las obras, las instalaciones y las actividades previstas por este Plan director sectorial no necesitan solicitar la condición de interés general en ejecución de lo dispuesto en el artículo 24 de la Ley de suelo rústico. 
La utilización como vertedero de residuos de construcción y demolición de una cantera, no se encuentra asimilada al concepto de «infraestructura pública» de acuerdo con el artículo 24 de la LSR, ni se encuentra entre las obras de infraestructura civil detalladas específicamente en el PDSRC y en consecuencia tampoco definida su localización en el territorio en el correspondiente anexo del plan. Todo ello conduce a que resulte ineludible la exigencia de la obtención de la declaración de interés general para la reconversión de una cantera para su destino a la acogida de residuos inertes, al ser un uso atípico del suelo rústico. Cuestión diferente será, al igual que la problemática tratada en otros puntos, el hecho de que la obtención de la declaración urbanística devenga reglada si concurren los requisitos previstos en el plan director.

A diferencia la previsión de acogimiento en las facultades del artículo 2.6.a de la $\mathrm{LDU}^{26}$, la actividad de vertedero de residuos inertes en una cantera no localizada en el PDSRC requerirá licencia urbanística. En este sentido, la sentencia del TSJIB n. ${ }^{\circ}$ 504/2002, de 28 de mayo de 2002, al analizar la legalidad de una resolución municipal de paralización y clausura cautelar del ejercicio de actividad consistente en vertidos de residuos sólidos urbanos en una cantera por carecer de licencia municipal recuerda que «la actividad de vertido en el subsuelo se encuentra sujeta a licencia municipal -artículo 2.5 de La Ley 10/90 - y el vertido no autorizado constituye una infracción urbanística en materia de medio ambiente -artículo 27.3.d de la Ley 10/90-», considerando que la autoridad urbanística, Alcaldía o Consell Insular, tiene que disponer la suspensión inmediata de todo acto del uso del suelo efectuado sin licencia, sobre la base de los artículos 61.1, en relación con el artículo 35 de la citada Ley, concluyendo que «siendo pacífico que la actora carecía de licencia urbanística para uso del suelo como el del caso, esto es, para vertido de residuos sólidos urbanos, la Alcaldía se encontraba obligada a adoptar la decisión de paralizar el vertido en cuestión».

En una línea similar se conforma la doctrina establecida por el mismo Tribunal en su sentencia n. ${ }^{\circ}$ 411/2003, de 13 de mayo de 2003, que aún

\footnotetext{
»Todas las obras, las instalaciones y las actividades incluidas en el servicio público insularizado y previstas en este Plan director sectorial tienen la consideración excepcional establecida por el artículo 2.6.a de la Ley 10/1990, de 23 de octubre, de disciplina urbanística y la prevista por el artículo único de la Ley 9/2000, de 27 de octubre, de modificación del a Ley 12/1999, de 23 de diciembre, de medidas tributarias, administrativas y de función pública y económicas».

${ }^{26}$ Dicho precepto dispone la sujeción a licencia previa, sin perjuicio del resto de autorizaciones procedentes, entre otras actuaciones: «6. a) Las obras de construcción de infraestructura civil tales como presas, viario público y privado, defensa y corrección de cauces públicos, puertos, diques, etc., excepto que tales actos hayan sido detallados y programados como obras a ejecutar en un Plan Especial o Plan Territorial o Plan Director Sectorial debidamente aprobado o autorizado».
} 
referida a la clausura provocada por el vertido de residuos no inertes, refleja la necesidad de concurrencia de las autorizaciones urbanísticas y de actividad, y a nuestro entender también por extensión aplicable a la autorización insular para la utilización atípica de un ámbito físico del suelo rústico.

\section{LA REVISIÓN DEL PDS DE CANTERAS Y LA LEY DE DIRECTRICES DE ORDENACIÓN TERRITORIAL}

Inicialmente hemos intentado contextualizar en el tiempo la aprobación del vigente PDS de Canteras, cuya revisión es aprobada mediante el Decreto 61/1999, de 28 de mayo, publicándose en el Boletín Oficial de nuestra Comunidad Autónoma el 5 de junio de 1999, es decir, una vez en vigor la Ley 6/1999, de 3 de abril, de Directrices de Ordenación Territorial de las Illes Balears. Resultaba evidente, a tenor de la vinculación de las determinaciones de las DOT a los planes directores sectoriales, que derivaba tanto de la previsión expresa de la LOT/87 como lógicamente del rango legal de las directrices, que las determinaciones de los primeros no podían contradecir en ningún caso a las segundas.

En esta línea, la LDOT al relacionar en su artículo 57 a los planes directores sectoriales ${ }^{27}$ aprobados con anterioridad que mantendrían su vigencia, dentro de una relación de hasta nueve instrumentos, aludirá al PDS de Canteras (lógicamente refiriéndose por razón temporal a su versión de 1997) aunque se cuida de precisar que dicha vigencia lo es «en todo lo que no contradiga esta ley». En definitiva la revisión del plan director, aprobada definitivamente una vez en vigor la LDOT, no podía por ello contradecir sus determinaciones aún cuando su proceso de gestación hubiera tenido lugar con anterioridad. Se efectuaba además un recordatorio expreso por parte de la Ley en su disposición transitoria primera, estableciendo una norma ad hoc según la cual, los planes territoriales parciales y los planes directores sectoriales en elabora-

\footnotetext{
27 Defectuosamente, el primer párrafo de dicho artículo dispone «los planes directores territoriales que ordenan infraestructuras o equipamientos que permanecen vigentes, en todo aquello que no contradiga esta ley, en el momento de entrar en vigor estas directrices, son los siguientes: ...» La incorrección radica en el hecho de que en base a cualquiera de las determinaciones de las dos leyes de ordenación territorial, la regulación de las canteras desde el punto de vista de la ordenación territorial mediante un PDS no podía entenderse ni como ordenación de infraestructuras ni de equipamientos, sino de actividades de explotación de recursos. En este sentido, se debería haber perfilado una doble distinción de PDS, incluyendo en el subgrupo de ordenación de actividades el relativo a canteras y los existentes de ordenación de la oferta turística.
} 
ción en el momento de su entrada en vigor, deberían adaptarse a sus determinaciones.

La revisión del PDS de Canteras fue objeto de diversas impugnaciones en vía contencioso administrativa, tanto por parte de Administraciones territoriales -algún ayuntamiento afectado por la previsión de actividades extractivas y por el Consell Insular de Mallorca-, como por parte de entidades y particulares afectados, en las que se invocaba infracción del contenido de las determinaciones de la LDOT. Por parte del TSJIB se confirmó en los expresados contenciosos la adecuación del PDS a las directrices, pero a nuestro criterio su pronunciamiento en este punto no llegó a culminarse totalmente.

Lo cierto es que los distintos recurrentes alegaban genéricamente infracción de la Ley de Directrices, pero en gran parte se vinculaban los citados alegatos a cuestiones de índole más general como fueron fundamentalmente la necesidad de incorporación al plan de un estudio de evaluación de impacto ambiental o la infracción del principio de autonomía local, en los términos que se han podido ver más arriba. Se explica así que el TSJIB no se pronunciase sobre una casuística más extensa en el punto de la hipotética infracción legal realizada por parte del plan, como decimos consecuencia de una falta de concreción por parte de los recurrentes de las determinaciones del PDS que supuestamente infringían las directrices de ordenación territorial.

Reflejo de la situación, son las consideraciones que realiza el TSJIB en su sentencia n. $^{\circ} 674 / 2002$, de 26 de julio de 2002:

«El anterior argumento de impugnación no puede ser estimado, pues con independencia de señalar que la parte actora, fuera de los casos de los artículos 85 y 86 mencionados, no ha querido o no ha sabido concretar esas «otras determinaciones» denunciadas, exigidas por las DOT y no recogidas en el Plan Director Sectorial de autos, por lo que es imposible pronunciarse sobre ellas, es lo cierto que, como se ha afirmado en el primer fundamento de esta resolución, en la Memoria se recogían los análisis, diagnósticos, estudio de impacto ambiental y valoración de los recursos naturales afectados, conforme impone la Ley 6/99, cumplimentando así lo dispuesto en la Disposición Transitoria Primera de ésta, sin olvidar que el artículo 57 se refiere a este Plan Director Sectorial, y que, la Disposición Adicional Primera, establece que "todos los criterios establecidos en esta Ley para la redacción de los instrumentos de ordenación territorial se interpretarán de acuerdo con los aprobados por el Parlamento de las Islas Baleares, según la disposición transitoria única de la Ley 8/87, de 1 de abril, de ordenación territorial de les Illes Balears». Consecuencia pues, teniendo en cuento lo dicho y además el contenido del artículo 22 de la Ley de Ordenación Territorial, no se aprecia esa vulneración del principio de jerarquía denunciada, pues es claro que, en principio, dicho Plan Director Sectorial discutido se ajusta a la normativa de rango superior. 


\begin{abstract}
„Como corolario de la anterior denuncia, la parte actora se fija a continuación, para solicitar la anulación del Decreto impugnado, en la infracción del procedimiento normativamente establecido, ya que considera que documentos tan esenciales como son el estudio económico de los recursos naturales y la evaluación de impacto ambiental, no fueron aprobados inicialmente, ni han sido sometidos al preceptivo trámite de información pública.
\end{abstract}

»Pues bien, tampoco este razonamiento de oposición a la legalidad del Decreto, debe ser estimado, y ello no sólo por lo mencionado anteriormente por aplicación de la Disposición Transitoria Primera de la Ley 6/99, sino sobre todo porque la exigencia del «estudio de acuerdo con la normativa específica de evaluación de impacto ambiental», a que se refiere el art. 85, no es precisamente un EIA, de los previstos en el Decreto 4/1986, ni en el R.D. 1302/1986, de 28 de junio, tal y como se precisa en la Disposición Adicional Séptima, al señalar que "el Gobierno de les Illes Balears promoverá la regulación de los estudios de impacto ambiental de los instrumentos de ordenación territorial y de los instrumentos de planeamiento general», refiriéndose con ello a una normativa futura, que en la fecha de la publicación del Decreto ni siquiera se había comenzado. Diferencia lógica, si se piensa y se acude a la sentencia de esta Sala-mencionada por el actor en su demanda-n. ${ }^{\circ} 224$ y fecha 9 de abril de 1999, donde se exigía la información pública de EIA, referida a una actuación concreta, como era la concesión para la construcción y explotación de la ampliación de un refugio de embarcaciones. Es decir, como afirma el Letrado de la Administración demandada el Plan Director Sectorial no construye canteras, ni autoriza por si mismo la excavación o construcción de canteras, sino que, tal como se recoge en el artículo 6 de la Ley de 1987 y ahora en los artículos 11 y 12 de la LOT de 2000, establecen una regulación del planeamiento territorial en el sector. En resumen, cabe rechazar la argumentación indicada, por la transitoriedad del Plan Director cuestionado, y por su generalidad u ausencia de normativa específica sobre la materia».

En similar sentido, se pronuncia la sentencia del mismo Tribunal $\mathrm{n}^{\mathrm{o}}$. 993/2002, de 3 de diciembre de 2002, que se reproduce en las consideraciones de la $\mathrm{n}^{\circ}$. 457/2003, de 29 de mayo de 2003. A nuestro entender, dejando ahora de lado el posterior análisis de la regulación minera y medioambiental que pudieran exceder del título habilitante del planificador en ordenación territorial, interpretándose las determinaciones de vinculación al planeamiento municipal desde la perspectiva que hemos intentado ofrecer más arriba, e igualmente partiendo del mantenimiento de las competencias supramunicipales en materia urbanística que tenían atribuidas los consells insulares, podríamos concordar en la adecuación del PDS a la legalidad.

Como mínimo, nuestra interpretación relativa al mantenimiento de las competencias de intervención de los consells insulares en el trámite de declaración urbanística de interés general de la actividad extractiva y la necesaria concurrencia de las autorizaciones municipales previstas en la LDU y la Ley 8/1995 no son cuestionadas por el TSJIB, por no decir que en el caso de aquellas últimas son expresamente revalidadas. A nuestro 
entender, el único punto de infracción evidente del PDS de alguna determinación de la LDOT era su interacción con las que la última denomina «áreas de transición», constituyendo una subcategoría de suelo rústico colindante a las zonas de asentamiento urbano en que la matriz de ordenación prevista en la norma legal prohíbe expresamente las actividades extractivas, mientras que el PDS grafía alguna de estas áreas como posibles zonas de localización de recursos.

Aspecto el anterior que, entre otros, fue impugnado por parte del Consell Insular de Mallorca pero considerándose por el TSJIB lo siguiente, en la aludida sentencia n. $^{\circ}$ 457/2003, de 29 de mayo de 2003:

"Assenyalarà, a més, la part actora, que el mapa de zones de localització de recursos d'interès miner grafia algunes zones que són confinants amb nuclis urbans, cita com exemples a Mallorca, les de Santanyi i platja del Arenal, i a Menorca, les d'Alaior i Ferreries, la qual cosa suposa vulnerar allò que ve establert a les àrees de transició.

»Dèiem, però, en qualsevol cas, a l'esmentada sentència 241 de 2003, que «toda explotación de canteras conlleva inevitables perjuicios al medio ambiente y que precisamente una de las singularidades de la Revisión del Plan es la de establecer una regulación «de forma que las canteras ocasionen un menor impacto ambiental» (art. $1^{\circ}$ ). Para ello se establecen unos criterios generales que en la aplicación al caso concreto en unos casos supondrá la apertura de la cantera y en otros no. La indicación de cuales deben ser las prioridades y finalidades del Plan es una facultad exclusiva del planificador, en este caso la Comunidad Autónoma que ha de fijar aquellos criterios y parámetros que considere prioritarios».

A nuestro entender la remisión del Tribunal a la anterior sentencia no aclaraba en que medida se podía considerar que el PDS no infringiera las determinaciones de prohibición legal de implantación de actividades extractivas en las áreas de transición.

Debemos por tanto interpretar que el TSJIB salva el escollo en la medida en que un criterio general del plan, aplicado a una hipotética localización solapada en un caso concreto con la categoría urbanística de área de transición definida en la LDOT quedaría neutralizado y con ello se impediría la apertura de la cantera en una zona donde la ley proscribe esta actividad. Decimos que es una manera de salvar el escollo puesto que, si bien se puede entender que hubiese resultado compleja la derogación del PDS en este punto, la Sala fácilmente podría haber utilizado una fórmula expresa para la superación de esta situación, no con una remisión confusa a una resolución anterior dictada por el mismo órgano de la jurisdicción, sino con la fijación de un criterio interpretativo del plan en este punto en la línea que hemos sugerido. 
Curiosamente, el aspecto de mayor conflictividad jurídica que bajo nuestro punto de vista ofrece del PDS como es el de su posible exceso en el objeto de regulación material, no fue esgrimido en ninguno de los numerosos procedimientos de impugnación antes aludidos. Por ello lógicamente, la doctrina generada por el máximo órgano jurisdiccional de nuestra Comunidad Autónoma no efectuó en ningún caso un análisis del Decreto de aprobación del PDS desde la perspectiva de normativa adicional de protección medioambiental o de desarrollo de legislación minera, sino estrictamente desde la vertiente de su contenido relativo a la ordenación territorial de una actividad de explotación de recursos. Planteamos por ello en el siguiente apartado la hipotética ilegalidad de las previsiones del PDS en materia medioambiental y minera.

\section{LAS PREVISIONES DEL PDS CON CONEXIÓN A OTROS TÍTULOS DE HABILITACIÓN}

\section{Naturaleza jurídica de las previsiones del Plan en materia minera y medioambiental}

Hemos intentado delimitar a lo largo del presente trabajo el correspondiente título habilitante de las diversas determinaciones establecidas en el PDS. Sin duda, existen toda una serie de prescripciones que tienen un encaje evidente en lo que se configura como la regulación, desde la perspectiva de la ordenación del territorio, de una actividad de explotación de recursos como son las canteras. A la vez, resulta meridianamente claro que confluyen en otras de sus determinaciones títulos de intervención en materia medioambiental y minera, e incluso en algunos aspectos derivados de la competencia sobre la regulación de patrimonio histórico de interés para la comunidad autónoma.

Dejemos claro que no hemos intentado cuestionar en ningún momento la posibilidad de que goza la CAIB para introducir en el ordenamiento jurídico autonómico previsiones de aquellos órdenes de regulación material como las contenidas en el PDS de Canteras. Pero la cuestión recurrente a lo largo de toda nuestra exposición se ha centrado en dilucidar si su materialización es posible mediante su incorporación a planes de ordenación territorial, o si por el contrario se requiere su formalización mediante la aprobación de una norma reglamentaria entendida en sentido estricto.

Recordando las consideraciones sobre las posibilidades de regulación en un instrumento de ordenación territorial de determinaciones pertene- 
cientes a otros órdenes que efectuaba el TSJIB que hemos efectuado más arriba, una vez más la Sala nos trazará indirectamente el camino a seguir.

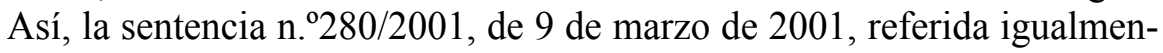
te a la impugnación del Decreto de aprobación de la revisión del PDS, viene a establecer:

«Con todo, por lo que se refiere a los fundamentos de la impugnación del caso, en cuanto a la falta de dictamen del Consell Consultiu, debe tenerse en cuenta, ante todo, que si bien el Plan Director Sectorial puede gozar de naturaleza normativa, sin embargo, no se trata de una verdadera disposición reglamentaria, de modo que, circunscrita la intervención del Consell Consultiu a los proyectos de reglamentos, no era precisa la emisión de dictamen previo en el caso puesto que el Plan Director Sectorial es un acto administrativo, finalizando el procedimiento para su aprobación con la aprobación definitiva del Consell de Govern mediante Decreto -artículo 24.1.d. de la Ley 8/87-».

El PDS tiene pues naturaleza normativa, pero no se trata de una norma reglamentaria stricto sensu. En definitiva, el TSJIB traslada aquí la doctrina consolidada relativa a la naturaleza jurídica de los planes de urbanismo, que aún incorporando algunas de las características que se predican de las normas reglamentarias, no se identifican plenamente con ellas. Desde este prisma se debe interpretar el apartado 2 del artículo 3 de la LOT/2000, en virtud del cual una vez aprobados y publicados oficialmente, los planes territoriales insulares y los planes directores sectoriales formaran parte del ordenamiento jurídico como disposiciones reglamentarias, aunque aclarando que para su elaboración, se seguirá el procedimiento establecido en aquella ley.

Todo ello conduce a la cuestión central: las previsiones en materia minera y medioambiental del PDS se efectúan exclusivamente en uso de las respectivas habilitaciones comunitarias y suponen reglamentación adicional de normativas sectoriales establecidas fuera del instrumento de ordenación territorial. Si ello es así, en congruencia, las hipotéticas innovaciones se deberían introducir en el ordenamiento jurídico por el mismo procedimiento de elaboración de las normas reglamentarias que resulten modificadas o complementadas estrictamente desde aquellos ámbitos de regulación sectorial que no sean derivadas del ejercicio de la competencia en ordenación del territorio.

Como hemos podido ver, se producen ambas situaciones - modificación y complemento normativo-. El RD 2994/1982 resulta complementado sin una específica conexión con las determinaciones de ordenación territorial del PDS por parte de todo su artículo 12, excepto en el párrafo final de su número 2. Tanto es así, que sus previsiones podrían operar en la práctica autónomamente del resto de disposiciones del PDS de orden estrictamen- 
te territorial; lo mismo podemos predicar del régimen de las fianzas de restauración, que no supone otra cosa que despliegue normativo en materia reguladora de explotación de recursos mineros.

Se producen igualmente modificaciones tácitas y expresas a una norma reglamentaria autonómica ajena al título de ordenación territorial, como es el Decreto 4/1986. Así, el artículo 12 y la disposición adicional sexta del PDS modifican el régimen de informes y los supuestos objeto de evaluación de impacto ambiental.

Expuesto lo anterior, surge el interrogante final: ¿Son ilegales las determinaciones del PDS que exceden claramente del ámbito de intervención del planificador en ordenación territorial? Evidentemente serían los órganos de la jurisdicción contenciosa quines tendrían en su caso que ofrecer la respuesta final pero, como quiera que en estos momentos difícilmente se podrá dar el caso -como razonadamente expondremos más adelante-, nos aventuramos a realizar una serie de consideraciones, partiendo del estudio de las posibilidades de convalidación de las previsiones del plan director al haberse aprobado en su momento por el mismo órgano que ostentaría las competencias para la aprobación de normas reglamentarias en materia medioambiental y minera: el Consell de Govern de la Comunidad Autónoma.

\section{Iters procedimentales y posibilidades de convalidación}

Avanzamos que el punto de inflexión para dar respuesta al anterior planteamiento será la necesidad de que en el procedimiento de elaboración de la norma reglamentaria reguladora del sector minero o medioambiental se requiera la emisión de dictamen por parte del órgano consultivo de la Administración de la CAIB, el Consell Consultiu de las Illes Balears puesto que, como hemos visto, tal trámite no deviene exigible en el procedimiento de aprobación de instrumentos de ordenación territorial. Dicho de otra forma, si en el procedimiento de elaboración de una disposición de carácter general «ordinaria» no se exigiera intervención de órgano consultivo, y en la medida en que existiese identidad sustancial de trámites en ambos procedimientos, se ofrecería una pauta para defender una convalidación de las determinaciones del PDS ajenas a la ordenación territorial.

Pero aún así, la respuesta no será tan fácil de obtener como pudiera parecer a primera vista. Veamos sino qué régimen jurídico era el aplicable en nuestra Comunidad Autónoma a la hora de elaborar una disposición de 
carácter general en el momento en que se aprueba definitivamente el PDS que nos ha ocupado.

En el año 1999 el procedimiento de aprobación de planes directores sectoriales se encontraba regulado como ya sabemos en la LOT/87. Los trámites en ella previstos, sucintamente, consistían en la elaboración de un dictamen por parte de la Comisión de Coordinación de Política Territorial, la aprobación inicial del plan, sometimiento a un período de información pública de dos meses, informe de la Delegación de Gobierno, de los consells insulares afectados y de los respectivos ayuntamientos, así como de los organismos y entidades que su ámbito de actuación tuviera incidencia con el objeto de regulación del plan y que se considerasen de interés a criterio de la expresada Comisión de Coordinación de Política Territorial y que así se señalasen en el acuerdo de aprobación inicial. Posteriormente tenía lugar la aprobación provisional por parte de la Comisión, siendo elevado al Consell de Govern para su aprobación definitiva mediante Decreto.

Por otra parte la Ley 5/1984, de 24 de octubre, de Régimen Jurídico de la Administración de la $\mathrm{CAIB}^{28}$, no regulaba expresamente el procedimiento de elaboración de disposiciones generales, si bien introducía algunos puntos con relación al ejercicio de dicha potestad reglamentaria (artículos 35 a 41), así, ordenaba que las disposiciones que emanasen del Gobierno adoptarían forma de Decreto (la misma forma y rango que exigía la LOT para la aprobación definitiva de planes directores). Ante el vacío procedimental, era forzosa la remisión a las previsiones de la Ley de Procedimiento Administrativo (artículos 129 a 132) y ya en el contexto del año 1999 en que produce la aprobación definitiva de la revisión del plan, a la aplicación supletoria de la Ley 50/1997, de 27 de noviembre, del Gobierno; en donde se regula el procedimiento de elaboración de los reglamentos en su artículo 24, derogando expresamente los anteriores preceptos vigentes de la Ley de Procedimiento Administrativo.

Todo ello, como hemos indicado anteriormente, para averiguar en que medida se podía producir una identidad sustancial de trámites en ambos procedimientos especiales. Conducía lo anterior a que de facto los trámites garantistas en cuanto a participación colectiva prácticamente iban a la par, excepto en lo relativo a la posible presencia de un acto de trámite cua-

\footnotetext{
28 Derogada inicialmente de forma parcial por la Ley 4/2001, de 14 de marzo, del Govern de las Illes Balears, y finalmente, en los preceptos que continuaban vigentes, por la nueva Ley $3 / 2003$, de 26 de marzo, de régimen jurídico de la Administración de la CAIB.
} 
lificado que podía concurrir en el procedimiento de elaboración de disposiciones generales como era la intervención del órgano consultivo. Dicha intervención no era en ningún caso necesaria, como ya hemos podido ver en el procedimiento de elaboración de un PDS.

La Ley 5/1993, de 15 de junio, del Consell Consultiu, en su redacción inicial, preceptuaba la intervención obligatoria del órgano dictaminante en los «proyectos de disposiciones reglamentarias o de carácter general que se dicten en ejecución de las leyes y sus modificaciones» (artículo 10.2). Por consiguiente, el punto de inflexión relativo a la posible convalidación procedimental se debe considerar en la medida en que las disposiciones normativas del PDS en materia minera y medioambiental supusieran desarrollo normativo de las disposiciones de una norma de rango legal.

Es evidente que este no era el caso de las afecciones al Decreto 4/1986 que apareció en nuestro ordenamiento jurídico como norma reglamentaria autónoma, por lo cual su modificación expresa o tácita por parte del Decreto de aprobación definitiva del PDS pudiera ser aparentemente convalidable en el contexto normativo y temporal del año 1999. Problemática diferente produce el despliegue reglamentario sobre régimen minero, que para afrontarse se debería partir inicialmente de discernir si el PDS y sus determinaciones de este orden suponen solamente despliegue normativo del RD 2994/1982 en la medida que se establecen normas adicionales a las previstas en aquella disposición administrativa estatal, o si de hecho suponían más bien un desarrollo directo de la Ley de Minas ${ }^{29}$.

Actualmente, las cuestiones planteadas tendrían una clara respuesta. Partimos que a día de hoy resulta aplicable tanto la modificación operada en la norma legal reguladora del Consell Consultiu por parte de la Ley $6 / 2000$, de 31 de mayo, como por la entrada en vigor de la Ley 4/2001, de 14 de marzo, del Govern de las Illes Balears, que regula el procedimiento de elaboración de disposiciones administrativas en sus artículos 42 a 47 , normas que regulan ya con detalle el ejercicio de la potestad regla-

\footnotetext{
29 En este sentido existe un caso paradigmático en nuestra comunidad autónoma exponente de dicha problemática, como es el Decreto 2/1996, de 16 de enero, sobre regulación de capacidades de población en los instrumentos de planeamiento general y parcial, que supone despliegue de las disposiciones del TRLS/1976, y que fue por este motivo objeto de intervención de la Administración consultiva (dictamen 36/95, de 19 de diciembre); resultando que además su primera norma predecesora, el Decreto 27/1993, de 11 de marzo, de idéntica denominación, fue declarado nulo de pleno derecho por sentencia del TSJIB de 23 de mayo de 1995, basando dicha declaración en que en su elaboración se omitió el previo dictamen preceptivo del Consejo de Estado, al no contar a la sazón la CAIB con órgano superior consultivo propio en relación con el ejercicio de sus competencias.
} 
mentaria por parte de la Administración autonómica. Sus previsiones comportan la exigencia obligatoria del trámite de dictamen del órgano consultivo ante cualquier tipo de disposición de carácter general, sea para desplegar las disposiciones de rango legal, sea para la aprobación de un reglamento autónomo.

Así, el artículo 10.6 de la Ley reguladora del Consell Consultiu, en su redacción actual dispondrá la evacuación de dictamen del citado órgano asesor con carácter preceptivo en los «proyectos de disposiciones reglamentarias, excepto las de carácter organizativo, y sus modificaciones $\rangle^{30}$. Esta nueva redacción y alcance de la intervención de la Administración consultiva explica que una reciente modificación del Decreto 4/1986 haya tenido que ser dictaminada, trámite que no fue preciso llevar a cabo en el momento de la aprobación del texto inicial de la norma reglamentaria en atención a su carácter de reglamento autónomo.

En consecuencia, el marco legislativo actual ofrecería una respuesta clara: no sería posible introducir determinaciones ajenas al ámbito de ordenación territorial por parte del PDS, ya que los trámites exigidos para su aprobación no son idénticos a los requeridos para la elaboración de disposiciones de carácter general en sentido estricto. Por otra parte la posible convalidación de las ya repetidas determinaciones en el contexto legal vigente en el año 1999 sería posible con relación a las que hubieran supuesto modificación de las determinaciones del Decreto 4/1986, mientras que las relativas a régimen minero sólo lo serían en la medida en que no hubieran supuesto despliegue directo de la Ley de Minas, función que en definitiva era la llevada a cabo por parte del RD 2994/1982.

\section{El posible desarrollo de las determinaciones del PDS}

La disposición final primera del Decreto 61/1999, de aprobación definitiva del PDS faculta expresamente al conseller de Medio Ambiente, Ordenación del Territorio y Litoral y al conseller de Agricultura, Comercio e Industria para dictar las disposiciones oportunas para su aplicación; técnica de habilitación que no estará tampoco exenta de problemática. Por otra parte, supone una reiteración del reconocimiento expreso de la con-

\footnotetext{
${ }^{30}$ Precepto que deberá ponerse en conexión con el artículo 46 de la Ley 4/2001, de 14 de marzo, del Govern de las Illes Balears, en el procedimiento previsto para la elaboración de disposiciones administrativas se dispone que deberá ser sometido preceptivamente el proyecto de disposición a dictamen del Consell Consultivo en los casos previstos en la legislación reguladora de dicho órgano.
} 
fluencia de órdenes de regulación material distintos, al facultarse a órganos que ejercen distinta competencia en la estructura administrativa del Govern para el desarrollo normativo del plan.

Efectivamente, partiendo de la base que el Decreto efectúa expresamente la «aprobación definitiva» de un PDS, y a pesar de participar de la naturaleza de disposición de carácter general, no estaremos estrictamente ante un acto de aprobación de una norma reglamentaria estricto sensu. Dicho de otra manera, los decretos aprobatorios de una norma reglamentaria no producen su aprobación inicial, provisional o definitiva, sino que simplemente aprueban la disposición de carácter general.

Valga la anterior comparación en términos simplistas para poner de manifiesto el problema que genera la habilitación de la disposición final primera del referido Decreto 61/1999: ante una norma reglamentaria aprobada por el Consell de Govern de la Comunidad Autónoma, ningún problema existe en habilitar a órganos jerárquicamente inferiores a su desarrollo, tal y como se prevé por parte de la citada Ley 4/2001, de 14 de marzo, del Govern de las Illes Balears. Cuestión diferente es el régimen que se establece para los planes de ordenación territorial, que si bien se aprueban por el mismo órgano en forma de Decreto, su régimen jurídico se define íntegramente en la LOT/87, sin que se prevea en ésta última expresamente la posibilidad de desarrollo de sus determinaciones por habilitación a órgano jerárquicamente inferior.

Seria defendible que, analógicamente, dichos instrumentos de ordenación territorial en su caso fueran desarrollados a través de técnicas de planificación especial (art. 17 TRLS/1976), técnica de complemento aplicable a figuras cercanas a la planificación territorial previstas en el texto estatal como eran los planes directores territoriales de coordinación (cuya aplicación se desplaza en nuestra comunidad autónoma con la LOT/87). Pero aún sustituida la figura del plan director territorial de coordinación, ningún obstáculo existiría en orden a la posibilidad de aprobar planes especiales en la medida en que puedan complementar unas determinaciones de Planes Territoriales Insulares o Planes Directores Sectoriales cuando estos últimos así lo contemplasen.

En definitiva, ante la aprobación de un instrumento de ordenación territorial, no nos encontramos estrictamente, aún a pesar de la producción de efectos generales, frente al ejercicio de la potestad reglamentaria ordinaria que permite que una disposición administrativa faculte a un órgano jerárquicamente inferior a su desarrollo. Por el contrario nos situamos en un régimen jurídico específico de aprobación de instrumentos de ordena- 
ción territorial en el cual el acto de aprobación definitiva no puede habilitar a su desarrollo fuera de los márgenes que prevea la ley. Analógicamente un instrumento de planeamiento urbanístico general sólo puede ser desarrollado mediante los mecanismos de planificación de desarrollo parcial o especial, catálogos o normas complementarias, pero en ningún caso mediante la habilitación a un órgano específico a su desarrollo por un procedimiento diferente al de aprobación de planes.

Una interpretación basada en la distinción evidente de la naturaleza jurídica de estos dos tipos de disposiciones de carácter general, implicaría que la utilización de técnicas de desarrollo de instrumentos de ordenación territorial fuera de la planificación especial debiera como mínimo haberse contemplado, valga la redundancia, en el posible desarrollo reglamentario de la LOT, al que se autorizaba al Govern en virtud de su disposición final primera. Pero la hipotética previsión expresa no estaría tampoco exenta de problemática, puesto que si bien en el ámbito de los planes de competencia del Govern se podría arbitrar un procedimiento específico, en el ámbito de los consells insulares resultaría que este posible desarrollo debería afrontar el problema de que estos entes no disponen a día de hoy de potestad reglamentaria normativa en materia de ordenación territorial fuera del procedimiento estricto de elaboración de los planes de este orden.

Aún así, existen y son aplicados hoy en día ejemplos de esta dudosa técnica de desarrollo de la planificación territorial; tal es el caso de la Orden del conseller de Innovación y Energía, de 14 de octubre de 2002, por la que se desarrollan determinados aspectos relativos a los suministros y distribución de energía eléctrica en suelo rustico, norma dictada en virtud de una «habilitación» conferida por el artículo 18 del Decreto 58/2001, de 6 de abril, de aprobación definitiva del Plan director sectorial Energético de Balears.

\section{CONCLUSIONES}

Lo expuesto en el anterior apartado nos sirve para reafirmar nuestra opinión personal expuesta a lo largo del presente trabajo. Se ha regulado impropiamente en un instrumento de ordenación territorial, en un plan director sectorial, aspectos sustantivos y procedimentales con incidencia en materias ajenas al citado ámbito de intervención sobre las que ciertamente la CAIB ostenta competencia, pero no se han canalizado a través de los procedimientos adecuados. 
En cualquier caso, no dejan de ser determinaciones plenamente vigentes y aplicables cuya problemática legal deviene estrictamente de cuestiones de índole formal, que nunca fueron abordadas en los procesos jurisdiccionales de impugnación del Decreto de aprobación definitiva del PDS de Canteras. Esa situación comporta que actualmente ya no sea posible una impugnación del plan por vía indirecta, ante los actos administrativos singulares que deriven de la ejecución de sus determinaciones, puesto que la jurisprudencia restringe dicha posibilidad para los casos de infracción material o sustantiva, no siendo posible ante vicios formales referidos al procedimiento seguido para su elaboración y aprobación.

Llegados a este punto, debemos concluir con el apunte de una paradoja. Sabemos que los consells insulares no disponen de competencias en materia medioambiental y minera, y derivadamente tampoco resultan habilitados para el ejercicio de potestad reglamentaria normativa en estos campos, facultades que debería prever, en su caso, la correspondiente ley de transferencia o delegación intracomunitaria. Ello clarifica de por otra parte una cuestión: resulta obvio que los consells insulares no podrían elaborar un PDS con un contenido similar al vigente en lo relativo a las cuestiones medioambientales y mineras, sino que debería ceñirse a las determinaciones inicialmente analizadas en el presente trabajo cuyo contenido se refiriese a la incidencia territorial de las actividades extractivas, con independencia que supusiesen la neutralización de posibilidades autorizatorias de tipo minero por motivos de interés territorial supralocal, aunque sin modificar esta última reglamentación.

Neutralización que ha sido plenamente avalada en otros instrumentos de ordenación territorial. A modo de ejemplo, determinadas normas cautelares previas a la aprobación de los planes territoriales de las diferentes islas han comportado la suspensión de las posibilidades de autorizaciones sectoriales para la apertura de establecimientos de alojamiento turístico, partiendo de que tanto para los Planes Territoriales Insulares como para los Planes Directores Sectoriales de Ordenación de la Oferta Turística, se ha asignado competencia en orden a su elaboración y aprobación a los consells insulares.

Aún sin ostentar competencia normativa en materia de ordenación turística para el establecimiento de las condiciones de los establecimientos de alojamiento, resultará claro que el ejercicio de la competencia en materia de ordenación territorial puede impedir la concesión de las autorizaciones sectoriales turísticas mediante la prohibición urbanística del citado uso sobre un determinado ámbito físico, desde la perspectiva de la protección de un bien jurídico diferente del que protege la reglamentación 
estrictamente sectorial turística, pero sin que ello comporte usurpar competencias legislativas o normativas de ese orden ajeno a la ordenación territorial ${ }^{31}$.

Por tanto, los entes de gobierno y administración insular sí que disponen de competencia en materia de ordenación territorial en virtud de la Ley de atribución $2 / 2001$, de 7 de marzo, y expresamente resultan habilitados por la citada norma para llevar a cabo la elaboración del PDS de Canteras. Ante esta curiosa situación, resultará que teóricamente se posibilita que cada uno de los tres consells insulares puedan derogar en su ámbito territorial el PDS referido, bien para regular dicha actividad de explotación de recursos desde la perspectiva del plan territorial insular, bien para proceder a la modificación o revisión del instrumento de planificación sectorial. Este complejo entramado derivará en una situación inaudita en la que, de hecho, los consells insulares «derogarían», o más propiamente desplazarían en su ámbito territorial la aplicación de normativa reglamentaria elaborada por la Administración autonómica, factor que definitivamente demuestra el exceso del planificador en el proceso utilizado.

Al hilo de lo anteriormente expuesto, los futuros PDS revisados por los consells insulares solo podrán llevar a cabo una planificación de orden estrictamente territorial (ubicación de las actividades extractivas, integración ambiental y paisajística, establecimiento de vinculaciones al planeamiento municipal...), pero no efectuar una reglamentación ajena tanto desde la perspectiva del contenido material del PDS como desde la de habilitación normativa excepto en el caso de remisión a efectos identificativos o de neutralización de posibilidades de autorización sectorial efectuada desde la óptica territorial, en la línea trazada por el TSJIB aludida en otros puntos. En esta línea la reciente norma territorial cautelar aprobada por el Consell Insular de Menorca el 21 de marzo de 2005, previa a la elaboración de su PDS de Canteras, mediante la que se prohíbe cautelarmente el uso extractivo en el ámbito territorial de aquella isla, con la única excepción de las instalaciones que dispusieran ya de autorización o concesión, y que seguirán rigiéndose por el PDS balear.

\footnotetext{
${ }^{31}$ Gráficamente, si un municipio en la ordenación urbanística de una determinada zona residencial del suelo clasificado como urbano, prohíbe la implantación de usos de alojamiento turístico, resultará evidente que en dichas zonas no se podrán conceder autorizaciones sectoriales turísticas previas a la licencia. El plan general municipal urbanístico no deroga la reglamentación autonómica en materia de las condiciones mínimas de calidad de servicios o técnicas de las instalaciones de alojamiento, pero resulta evidente que no serán operativas las potestades de autorización previa autonómica en una zona en que se prohíbe, por ejemplo, la implantación de usos hoteleros.
} 
La justificación de la exposición de motivos de la citada medida cautelar obedece al establecimiento de normas en sintonía con su recientemente aprobado Plan Territorial Insular, que establece nuevas categorías de suelo rústico que inciden en la regulación de las actividades en ellas permitidas «afectando directamente la actividad extractiva y que determina que sea del todo necesaria la adaptación del PDS de Canteras» instrumento que deberá contribuir «de manera eficaz al modelo de desarrollo sostenible» de la isla; comportando el efecto legal atribuido por el artículo 17 de la LOT, de suspensión de licencias urbanísticas y autorizaciones sectoriales de cualquier orden que posibiliten nuevas actividades extractivas.

En definitiva, siendo loables los objetivos del vigente PDS de Canteras balear, el planificador, podría haber evitado toda la problemática apuntada si hubiera ceñido la regulación efectuada estrictamente al establecimiento de determinaciones claramente incardinables en la ordenación territorial; y regulando paralelamente, a través del procedimiento establecido para la elaboración de disposiciones de carácter general las condiciones propias de complemento, desarrollo o reglamentación autónoma en materia medioambiental y minera que se considerasen oportunas, y que resultarían así indisponibles por parte de los consells insulares mientras no les fuera transferida competencia en materia minera y medioambiental. De hecho, posiblemente la situación generada por la transferencia a dichos entes de la competencia para la elaboración del PDS de Canteras en virtud de la Ley 2/2001, aboque inexorablemente a la Administración de la Comunidad Autónoma a la inminente elaboración y aprobación de normas reglamentarias expresas y desligadas del instrumento de planificación territorial.

Ciertamente las opciones que podemos encontrar en otras comunidades autónomas en cuanto a la introducción de normativa propia reguladora de las condiciones de las explotaciones a cielo abierto pasan fundamentalmente por realizar esa innovación mediante la introducción de normas legales o reglamentarias entendidas en sentido estricto: normación sobre régimen minero, existiendo diferentes ejemplos que recopila Pérez Martos en su trabajo citado más arriba.

En lo relativo a la perspectiva de la ordenación sobre el territorio de una actividad de explotación de recursos como la efectuada por el PDS de Canteras de Baleares que hemos podido examinar, finalmente debemos cuestionar el sistema de planificación escogido.

Hemos apuntado su enorme complejidad, partiendo de una catalogación cuya consecuencia es que la ubicación sobre el territorio de unas acti- 
vidades con fuerte incidencia ambiental y paisajística se fija desde las preexistencias, a partir de las canteras ya activas ciertamente, pero también a partir de petrificar, nunca mejor dicho, desde la perspectiva del planificador territorial aquellas explotaciones autorizadas por la Administración minera aún no ejecutadas, y que perfectamente hubiesen podido quedar neutralizadas por el Plan Director, de haber transcurrido el plazo para su materialización.

Quiérase o no, se demuestra una perspectiva de ordenación demasiado simplista, que implica una renuncia a la planificación integral sobre un ámbito físico reducido y sensible como son los territorios insulares. No se plantea pues una opción que parta de cero a la hora de calibrar la enorme incidencia territorial y ambiental de una actividad de explotación de recursos naturales como la que nos ha ocupado. Se podrá argumentar que indirectamente el PDS de Canteras vigente realiza esa tarea concretando áreas físicas excluidas en el futuro para usos extractivos, pero lo cierto es que el gran número de instalaciones activas o «en cartera» que figuran en los catálogos incorporados comporta que el instrumento estudiado se haya quedado tal vez corto en sus posibilidades, más aún cuando se configura repleto de normas especiales y excepciones que en algún momento pueden hacer perder la perspectiva del concepto de planificación. 